\title{
Current Methods for the Discovery of New Active Ingredients from Natural Products for Cosmeceutical Applications
}

\section{(ㄷ) (i) (오 $\Theta$}

Authors

Claudia A. Espinosa-Leal, Silverio Garcia-Lara

\author{
Affiliation \\ Tecnologico de Monterrey, Escuela de Ingeniería y Ciencias, \\ Monterrey, N.L., México \\ Key words \\ bioactivity, natural products, cosmeceuticals, toxicity, \\ in vitro tests, active ingredient \\ received November 8, 2018 \\ revised February 7, 2019 \\ accepted February 9, 2019 \\ Bibliography \\ DOI https://doi.org/10.1055/a-0857-6633 \\ Published online March 29, 2019 | Planta Med 2019; 85: 535- \\ 551 @ Georg Thieme Verlag KG Stuttgart · New York | \\ ISSN 0032-0943 \\ Correspondence \\ Dr. Silverio Garcia-Lara \\ Instituto Tecnologico y de Estudios Superiores de Monterrey \\ Eugenio Garza sada 2501, 64849 Monterrey, Mexico \\ Phone: + 52 (81) 83284262 , Fax: + 52 (81) 83581400 \\ sgarcialara@itesm.mx
}

\begin{abstract}
Cosmeceuticals are designed to serve a dual purpose: to provide desired esthetical effects and to treat dermatological conditions. Natural products derived from plants and marine organisms are a novel source of potential cosmeceutical active ingredients for incorporation into new formulations due to consumer demands. Contrary to common perceptions, most regulatory agencies do not view cosmeceuticals as being a separate category from cosmetics; thus, these products are not regulated accordingly, thereby forcing the consumer to rely on the self-regulatory policies of the cosmetics industry. Cosmeceuticals are advertised as having capabilities that include anti-aging, anti-acne, solar-protective, wound healing, and skin whitening. Such traits normally comprise several biological activities. In order to ensure the safety and efficacy of these products, active ingredients employed in the formulations must undergo a series of tests. In this review, in vitro (enzymatic and cellular) and in vivo tests employed to evaluate the potential of new cosmeceutical active ingredients are discussed, and new trends that are being explored by the cosmeceutical industry are described.
\end{abstract}

$\begin{array}{ll}\text { ABBREVIATIONS } \\ \text { CFU } & \text { colony forming units } \\ \text { DMAB } & \text { para-Dimethylaminobenzaldehyde } \\ \text { ECM } & \text { extracellular matrix } \\ \text { EGCG } & \text { epigallocatechin gallate } \\ \text { FDA } & \text { Food and Drug Administration } \\ \text { FALGPA } & \text { N-[3-(2- furyl)acryloyl]-Leu-Gly-Pro-Ala } \\ \text { HA } & \text { hyaluronic acid } \\ \text { HEPES } & \text { 2-[4-(2-hydroxyethyl)piperazin-1-yl]ethane- } \\ & \text { sulfonic acid } \\ \text { ISO } & \text { International Organization for Standardization } \\ \text { L-DOPA } & \text { L-3,4-dihydroxyphenylalanine } \\ \text { MED } & \text { minimal erythema dose } \\ \text { SPF } & \text { sun protection factor } \\ \text { UVA-PF } & \text { UVA protection factor }\end{array}$

\section{Introduction}

The use of topical aides to improve physical appearance dates back worldwide to 6000 years in human history [1,2]. At present, the cosmetics industry accounts for $\$ 445$ billion dollars in sales annually, making it a highly desirable and competitive industry [3]. The flowers, seeds, roots, leaves, and fruits of plants have been used for their cosmetic properties, a practice that continues to this day [2].

The term cosmeceutical, referring to a hybrid substance between a cosmetic and a pharmaceutical, was first described by Raymond E. Reed in the 1960s as a substance that complies with the following points: (1) external application; (2) produces useful and desired results; (3) has desired esthetical properties; and (4) meets chemical, physical, and medical standards [2,4-6]. Thus, cosmeceuticals combine the esthetical properties of a cosmetic with the efficacy of a dermatological drug. Modern cosmeceuticals must achieve the accomplishment of 2 specific benefits: 


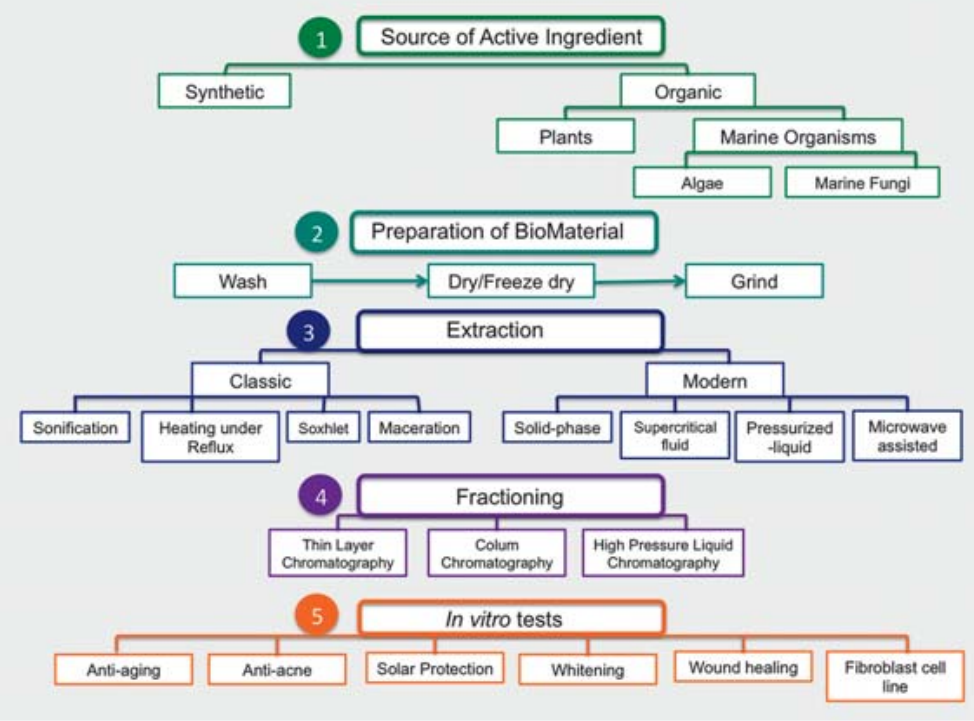

- Fig. 1 Basic steps needed for the discovery of new cosmeceutical active ingredients from natural products.

an immediate response (like a cosmetic) and a prolonged effect (like a pharmaceutical) [7]. Nevertheless, in recent years, the term has expanded to include any cosmetic that has or claims to have purported medicinal properties [5].

Most governmental offices worldwide, like the FDA in the United States, do not regularly recognize the term cosmeceutical, while Korea and Japan legally recognize 3 categories of products: cosmetics, functional cosmetics, and drugs [8]. This lack of recognition of this term has resulted in the grouping of these products as cosmetics or drugs, which complicates regulation [9]. In fact, most products are only self-regulated by the cosmetics industry [7].

One of the most widely spread misconceptions about cosmeceuticals is that the claims present in labeling and advertising are substantiated and approved before the products appear on the market. However, such claims are not always true [5]. Cosmeceutical products often use marketing to construct a "story" that links a certain active ingredient to the purported claims and benefits of the formulation [8]. Since no cosmetic company would consciously damage its own reputation with a problematic product that contains untested ingredients, the industry is in need of assays to test the cosmeceutical ability of new potentially active ingredients, especially those extracted from natural sources $[7,8]$.

This review aims to give a condensed overview of the process for new cosmeceutical development and to describe the most common tests employed in the development of new cosmeceutical active ingredients while also presenting new trends being explored by the cosmeceutical industry.

\section{Cosmeceutical Development}

The formulations of functional cosmetics, or cosmeceuticals, must include active ingredients that are recognized as safe and that provide some beneficial effect $[7,8]$. These active ingredients can be either synthetic (like most vitamins) or derived from natu- ral sources (extracts from plants, microorganisms, and animals). The use of specially designed assays to test the active ingredients can substantiate the claims of a new cosmeceutical [8]. An abbreviated guide to the steps necessary to obtain cosmeceutical active ingredients is presented in $\mathbf{r}$ Fig. $\mathbf{1}$ and more extensive accounts are explained in the following paragraphs.

As shown in > Fig. 1, the first step in the design of new cosmeceuticals is the selection of the source of the active ingredient. Plants have been employed by humans for hundreds of years to satisfy an array of different needs, including those of food, shelter, medicine, and cosmetics [10], as they are among the most bountiful sources of new ingredients present in the form of primary or secondary metabolites $[11,12]$. Plants are rich in endogenous antioxidants due to their existence in habitats that have severe UV radiation $[13,14]$. Plant metabolites with potential cosmeceutical applications include a varied list of structurally diverse compounds, such as phenolics, polyphenols, flavonoids, terpenoids, steroids, steroidal saponins, sterols, sugars, polysaccharides, lignans, carotenoids, organic acids, anthocyanins, and coumarins $[2,15]$. In addition, plant extracts are considered safe and have the requisite characteristics of cosmetic ingredients mandated by the FDA [7]. The cosmetics industry currently uses an array of plants, mostly belonging to the Asteraceae, Lamiaceae, Fabaceae, Poaceae, Malvaceae, and Rosaceae families [2]. Furthermore, studies are being conducted among native Canadian, Sri Lankan, and African plant species to find new ingredients [15-17].

Alternative sources of potentially active ingredients include marine organisms, which produce molecules that are chemically distinct from those of terrestrial sources. Polyphenols, for instance, are composed of phlorotannins rather than the usual structures, which possess biological activities that are attractive for the cosmeceutical industry [18-20]. Other metabolites of interest from marine organisms include polysaccharides, carotenoid pigments, collagen, chitooligosaccharide derivatives, enzymes, peptides, and other natural products [21-23]. Of special 
- Table 1 Plant secondary metabolite extraction methods. Table constructed with information modified from [24].

\begin{tabular}{|c|c|c|c|c|c|}
\hline Method & Equipment & Sample loading & Extraction & Solvent volume & Notes \\
\hline Percolation & Yes & $\begin{array}{l}\text { Plant material is wetted } \\
\text { with the solvent and } \\
\text { loosely packed in the } \\
\text { container; more solvent } \\
\text { is added to maintain the } \\
\text { plant material covered }\end{array}$ & $\begin{array}{l}\text { After soaking the percolator } \\
\text { valve is open slightly in order } \\
\text { to collect solvent saturated } \\
\text { with the solutes }\end{array}$ & $\begin{array}{l}\text { Large } \\
\text { Is replaced constantly }\end{array}$ & \\
\hline Soxhlet & $\begin{array}{l}\text { Yes } \\
\text { Commercial } \\
\text { options }\end{array}$ & $\begin{array}{l}\text { Wetted plant material is } \\
\text { loosely packed in the } \\
\text { container; sufficient sol- } \\
\text { vent is added to collect- } \\
\text { ing flask (no overflow) }\end{array}$ & $\begin{array}{l}\text { The solvent is refluxed } \\
\text { through the sample for a } \\
\text { determined number or cycles }\end{array}$ & $\begin{array}{l}\text { Small } \\
\text { Solvent is continuously } \\
\text { recycled }\end{array}$ & $\begin{array}{l}\text { The heat needed to drive the } \\
\text { extraction may destroy heat } \\
\text { liable compounds }\end{array}$ \\
\hline Maceration & $\begin{array}{l}\text { No } \\
\text { Erlenmeyer } \\
\text { flasks can be } \\
\text { used }\end{array}$ & $\begin{array}{l}\text { The plant material is } \\
\text { wetted with the solvent } \\
\text { and loosely packed in the } \\
\text { container; more solvent } \\
\text { is added to cover the } \\
\text { sample }\end{array}$ & $\begin{array}{l}\text { The sample with solvent is } \\
\text { allowed to stand and extract; } \\
\text { typically saturated solvent is } \\
\text { decanted and filtered; new } \\
\text { solvent is added, stirred, and } \\
\text { allowed to macerate over- } \\
\text { night }\end{array}$ & $\begin{array}{l}\text { Dependent of the } \\
\text { number of solvent } \\
\text { changes (commonly } \\
\text { no more than 3) }\end{array}$ & $\begin{array}{l}\text { To accelerate the process, } \\
\text { sonication or constant stirring } \\
\text { on a shaking table can be } \\
\text { employed; for small sample } \\
\text { sizes, extractions can be } \\
\text { carried in closed tubes using a } \\
\text { shaking mixer }\end{array}$ \\
\hline
\end{tabular}

interest are macro- and microalgae, which can be grown in a rapid and cost-effective manner in vitro. Some current examples include the use by a Greek company of sea fennel in sun care products and the use by an Italian company of Guam seaweed for anti-cellulite formulations [23]. Additionally, marine fungi have a great potential for the production of secondary metabolites, although few of these compounds are suitable for use as cosmetic ingredients [22].

Once the source of a possible active ingredient has been selected, the biological material is prepared. Generally, plants are first washed, then dried or freeze-dried, and finally they are ground to homogenize the sample and to provide the largest surface contact with the solvent system. Several extraction methods with the use of water or organic solvents, including sonification, heating under reflux, Soxhlet extraction, maceration, and percolation, can be employed ( $\vee$ Table 1 ). The choice of a solvent system is dependent on the type of metabolite being extracted. For extraction of hydrophilic compounds, polar solvents, like methanol or ethanol, are used, while the extraction of hydrophobic compounds requires nonpolar solvents like dichloromethane or hexane [25]. Modern extraction techniques include solid-phase, supercritical-fluid, pressurized-liquid, microwave-assisted, and surfactant-mediated techniques. These avant-garde technologies are more environmentally friendly than their predecessors and carry a set of technological advantages [26-28]. For example, ultrasound-assisted extraction methods use the power of ultrasound to break cell walls, causing the release of inner cell components. The main advantages of the technique include reduction of the amount of power, solvent, and the time need for extraction [28-31]. Additionally, it can be used for thermolabile compounds $[28,30]$; however, a comprehensive evaluation of the characteristics of the plant such as moisture content and particle size of the bioactive compound needs to be done to guarantee a high recovery $[28,31]$. Another interesting new method is supercritical fluid extraction, which uses a liquid in a state that has features of both a liquid and a gas. The supercritical fluid can enhance extraction yields as it can diffuse simply through solid materials because of its better transport properties [28,32]. It is a good process for the extraction of compounds that are thermally stable or have high boiling points; nevertheless, the high maintenance needed by the equipment and other factors such as supercritical fluid, raw materials, and co-solvents can prove disadvantageous [28, $29,33]$. Finally, microwave-assisted extraction is one of the most advanced extraction techniques. Its efficiency is owed to its ability to heat the matrix internally and externally without a thermal gradient, resulting in a higher efficiency of extraction with less time, energy, and solvent volume needed $[28,29,33]$. However, the method does present some drawbacks, including the need for processes like filtration or centrifugation to remove solid residues. Moreover, the method is restrictive when it comes to nonpolar compounds extractions and can alter the chemical structure of target compounds [28, 29, 33, 34].

Additionally, in order to make the extraction process more "green" or "environmentally friendly," several changes can be made, including the use of alternative solvents, such as water and agro- or bio-solvents (renewable resource produced from biomasses, such as bio-ethanol) to reduce the consumption of energy and renewable biological materials [25, 35].

Plant and marine organisms produce a great number of metabolites, and extracts are formed by a combination of compounds. In order to be used in cosmeceutical formulations, some extracts must be fractioned to isolate compounds with biological activities. Usually, the extracts are first fractioned in several parts that contain molecules of similar polarity or molecular size. The fractions are then tested in vitro, using some of the techniques listed below in the Bioactivity analysis of cosmeceutical properties section for cosmeceutical activities. Then the active fractions are further separated to isolate the active metabolite using techniques like thin-layer chromatography, column chromatography, flash 
- Table 2 In vivo and In vitro tests employed for the safety assessment of cosmetics. With information from [38, 39].

\begin{tabular}{|c|c|c|}
\hline Assessment & In vivo model & In vitro model \\
\hline Acute toxicity & $\begin{array}{l}\text { - Administration of the ingredient (by oral, dermal, } \\
\text { or respiratory route) to rabbits, rats, or mice for the } \\
\text { calculation of the dose causing } 50 \% \text { of animal deaths } \\
\left(\mathrm{LD}_{50}\right)\end{array}$ & $\begin{array}{l}\text { - Software packages based on quantitative structure activity } \\
\text { relationships (QSAR) models } \\
\text { - Predict toxicity based on chemical structures }\end{array}$ \\
\hline Skin corrosion or irritation & $\begin{array}{l}\text { - Use of rabbits or other species such as guinea pig } \\
\text { and mouse } \\
\text { - Human volunteers }\end{array}$ & $\begin{array}{l}\text { - EpiSkin: Dermal substrate generated on type I bovine collagen } \\
\text { matrix, with a film of type IV human collagen, upon which is } \\
\text { laid all epidermal layers of native skin. } \\
\text { - EpiDerm: Human epidermal keratinocytes as fully- } \\
\text { differentiated epidermal tissue. } \\
\text { - TER: Skin from young rats. } \\
\text { OECD } 430 \text { [40] } \\
\text { - SkinEthic: Normal human keratinocytes cultured on inert } \\
\text { polycarbonated filters } \\
\text { - epiCS: Normal human epidermal keratinocytes from a single } \\
\text { neonatal donor supplied in 24-well formats. } \\
\text { - RHE: Reconstructed human epidermis OECD 431 [41] } \\
\text { - In vitro membrane barrier test OECD 435 [42] }\end{array}$ \\
\hline Eye irritation & $\begin{array}{l}\text { - Draize conventional test (use of albino rabbits) } \\
\text { - Human volunteers }\end{array}$ & $\begin{array}{l}\text { - EpiOcular: 3D model, Non-keratinized epithelium prepared } \\
\text { from normal human keratinocytes. } \\
\text { - HCE: 3D model, immortalized human corneal epithelial cells }\end{array}$ \\
\hline Skin sensitization & $\begin{array}{l}\text { - } \text { Animal Tests: } \\
\text { - Mouse local lymph Node assay (LLNA), } \\
\text { - } \text { Nonradioactive modifications: LLNA-DA and } \\
\text { LLNA-BrdU ELISA } \\
\text { - } \text { Guinea pig maximization test by Magnusson and } \\
\text { Kligman (GPMT) } \\
\text { - Buehler occluded patch test in the guinea pig } \\
\text { - Human volunteers: patch test }\end{array}$ & $\begin{array}{l}\text { - Direct peptide: Haptenation process is reproduced in vitro } \\
\text { - Reactivity assay KeratinoSens: Immortalized adherent human } \\
\text { keratinocyte cell line (HaCaT cell line), transfected with a } \\
\text { selectable plasmid to quantify luciferase gene induction as a } \\
\text { measure of activation of Keap1-Nrf2-antioxidant/electrophile } \\
\text { response element (ARE) } 1\end{array}$ \\
\hline Genotoxicity & - Comet test in animals (rats) & $\begin{array}{l}\text { " Micronucleous test: Formation of “micronucleus" (part of a } \\
\text { chromosome not incorporated into one of the daughter nuclei } \\
\text { during cell division) }\end{array}$ \\
\hline Carcinogenicity & $\begin{array}{l}\text { Animal tests: induction of tumors or cancer in rats, } \\
\text { mice, or rabbits via oral or dermal administration of } \\
\text { the test subject. }\end{array}$ & $\begin{array}{l}\text { - BALB/c 3T3: Based on the malignant transformation of } \\
\text { immortalized embryonic mouse fibroblasts } \\
\text { - SHE: Syrian hamster embryo cell }\end{array}$ \\
\hline $\begin{array}{l}\text { UV-induced toxic effects/ } \\
\text { phototoxicity }\end{array}$ & $\begin{array}{l}\text { - Animal tests } \\
\text { - Human volunteers }\end{array}$ & $\begin{array}{l}\text { 3T3 NRU: Uses normal BALB/c } 3 \text { T3 mouse fibroblasts to } \\
\text { measure the concentration dependent reduction in neutral } \\
\text { red uptake by the cells after exposure to a test material } \\
\text { either in the presence or absence of UVA light. }\end{array}$ \\
\hline
\end{tabular}

chromatography, and high-performance liquid chromatography, among others [25, 36].

After confirmation that the isolated compound has cosmeceutical activity, it is tested in vitro using fibroblasts, a cell type that represents the main dermic population and is considered a good safety model due to its responsiveness (see Section 4a). The goal of the test is to maintain homeostasis of the ECM and elevate the production of some important dermal components, such as collagen and elastin. The isolated active ingredient is then placed in suitable vehicles and tested in vivo in human clinical studies $[7,37]$. The best formulations can then be released to the marketplace.

It is important to point out that during this process the extracts are constantly tested for activity and toxicity so as to ensure safety. The guidelines used for cosmetics can be employed to test the safety of cosmeceuticals. Cosmetics are required to be safe for consumer use in accordance with the directions in the labeling or in a customary or expected way [9]. Typically, in order to assess the safety of a particular cosmetic, the manufacturer must test the safety of each ingredient present in the formulation. In this respect, a "natural" or "organic" (words often used to describe plant extracts or natural products) ingredient is not guaranteed to be safe and thus must be tested like any other cosmetic ingredient [9]. Standard safety tests are listed in $\mathbf{~ T a b l e ~} 2$. Changes in legislation, specifically in the European Union, have encouraged the creation of in vitro tests so as to evaluate the safety of cosmetic ingredients, since the use of animal tests was prohibited in Europe in 2004 for cosmetics and in 2009 for cosmetic ingredients [38]. A recent review by Almeida et al. [38] has provided insights into the in vitro models for safety and toxicity assessments of cosmetic ingredients and some of the in vitro tests currently accepted by the Organization for Economic Co-operation and Development. Traditional in vivo tests are listed in $>$ Table 2. 


\section{Bioactivity Analysis of Cosmeceutical Properties}

Cosmeceutical products can be classified according to the type of activity provided by the active ingredients. Marketing teams usually advertise the benefits of cosmetics with the use of undefined phrases like "anti-aging" and "skin toning" that can imply a range of biological activities [8]. The following section lists those cosmeceutical properties that are most important and recurrent and the most common tests that are used to demonstrate the biological activities of ingredients.

Anti-aging

The skin is an organ that easily presents signs of aging due to the weakening of the elasticity and strength of the skin, which results in wrinkle formation [43-44]. Two types of aging affect the skin: intrinsic or age-dependent and extrinsic or photoaging [16,4546]. Intrinsic aging is affected by various factors, such as telomere shortening, the imbalance between free radicals and antioxidants, and hormonal changes, while photoaging is promoted by exposure to UV solar radiation [43-45, 47-49].

The skin consists of 3 layers: the epidermis, dermis, and hypodermis $[16,50]$. The outer most part of the skin, epidermis, is followed by the dermis, which is mainly formed by the EMC, fibroblast, and protein fibers composed of collagen and elastin [16, 51]. Collagen accounts for about $80 \%$ of dry skin weight and is responsible for the tensile strength and maintaining flexibility of the skin. Elastin fibers, on the other hand, provide elasticity to the skin. HA helps to retain moisture of the skin as well as its structure and elasticity. It is also involved in rapid tissue proliferation, regeneration, and repair $[16,52,53]$. Aging causes decreases in the levels of collagen, elastin, and $\mathrm{HA}$ via several pathomechanisms (a mechanism by which a pathological condition occurs), including enzymatic degradation of the elastin fibers and collagen networks and the attack of fibroblast components by free radicals, which are responsible for the formation of collagen, elastin, and HA $[44,54,55]$.

Active ingredients that possess inhibitory actions against elastase, collagenase, and hyaluronidase (enzymes that degrade elastin, collagen, and $\mathrm{HA}$, respectively), as well as antioxidant activities, could help to decelerate skin aging [44]. The following paragraphs detail the methods employed for the testing of anti-aging enzymatic activities. Antioxidant activity assays are omitted since they have been extensively discussed in other reviews [56].

\section{Anti-collagenase test}

The most commonly used anti-collagenase test, developed by Van Wart and Steinbrink in 1981 [57], is based on the enzyme-substrate interaction between collagenase, typically derived from Clostridium histolyticum, and FALGPA, a synthetic proteolytic compound that results in a reduction in absorbance between 324 and $345 \mathrm{~nm}$. Pre-incubation of the enzyme with an inhibitor, such as a bioactive compound or plant extract, results in the limited breakdown of FLAGPA and conservation of the absorbance [44]. Most plant extracts have low yields, and in order to economize reagents, it is more efficient to employ micro-scale methods, such as that described in the study by Chattuwatthana and Okello [44], where $20 \mu \mathrm{L}$ of $50 \mathrm{mM}$ 2-[[1,3-dihydroxy-2-(hydroxymethyl)propan-2-yl]amino]ethanesulfonic acid buffer with $0.36 \mathrm{mM}$ calcium chloride ( $\mathrm{pH} 7.4$ at $37^{\circ} \mathrm{C}$ ) is placed in the wells of a 96 -well microtiter plate together with $20 \mu \mathrm{L}$ of collagenase derived from C. histolyticum. Then the test substance (plant extracts, fractions) is added and the mixture is allowed to react in the dark at $37^{\circ} \mathrm{C}$ for $20 \mathrm{~min}$. To separate wells, $20 \mu \mathrm{L}$ of EGCG was added as a positive control and $20 \mu \mathrm{L}$ of $18.2 \mathrm{M} \Omega$ water was added as a negative control. After the first incubation period, $40 \mu \mathrm{L}$ of FALGPA working solution is added to each well to a final reaction volume of $100 \mu \mathrm{L}$. The microplate is then incubated in the dark at $37^{\circ} \mathrm{C}$ for $30 \mathrm{~min}$. As the final concentration of the reaction mixture, $0.8 \mathrm{mM} \mathrm{FALG-}$ $\mathrm{PA}, 0.16 \mathrm{U} / \mathrm{mL}$ of collagenase, and $0.023 \mathrm{mg} / \mathrm{mL}$ of EGCG were used as a positive control. Finally, the absorbance of the solution is determined using a microplate reader at $335 \mathrm{~nm}$. A blank is used to correct the background absorbance of the plant samples and controls. The percentage of collagenase inhibitory activity is then calculated using Eq. 1.

collagenase inhibition $(\%)=\left(1-\frac{\mathrm{S}}{\mathrm{C}}\right) \times 100$

Where $S$ is the corrected absorbance of the samples containing the collagenase inhibitor (enzyme activity in the presence of the sample) and $C$ is the corrected absorbance of the negative control (enzyme activity without the sample) [44].

\section{Anti-elastase test}

The basic principles of the anti-elastase test, as first described in the study by Kraunsoe et al. [58], are that elastase directly breaks down the elastin substrate, causing a change in the absorbance that can be measured with a spectrophotometer [44]. Ndlovu et al. [16] in their study described a modified micro-method, where the wells of a 96 -well plate are filled with $25 \mu \mathrm{L}$ each of $0.1 \mathrm{M}$ HEPES buffer $(\mathrm{pH} 7.5)$, the test sample $(1.4 \mathrm{mg} / \mathrm{mL})$, and elastase $(1 \mu \mathrm{g} /$ $\mathrm{mL}$ ). Blank wells are filled with $75 \mu \mathrm{L}$ of HEPES buffer and negative controls with $25 \mu \mathrm{L}$ elastase and $50 \mu \mathrm{L}$ HEPES buffer, while positive controls received $25 \mu \mathrm{L}$ each of elastase, HEPES buffer, and elafin/ $\mathrm{N}$-methoxysuccinyl-Ala-Ala-Pro-Chloro $(10 \mu \mathrm{g} / \mathrm{mL})$. Solvent controls consist of $25 \mu \mathrm{L}$ each of elastase, HEPES buffer, and a $10 \%$ solution of the solvent to dissolve the sample. Running color controls of each of the samples tested using $150 \mu \mathrm{L}$ of HEPES buffer and $25 \mu \mathrm{L}$ of the sample is recommended. Then the plate is incubated at room temperature $\left(25^{\circ} \mathrm{C}\right)$ for $20 \mathrm{~min}$. Afterward, $100 \mu \mathrm{L}$ of the substrate $\mathrm{N}$-methoxysuccinyl-Ala-Ala-Pro-Val-p-nitroanilide $(1 \mathrm{mM})$ is added and the plate is further incubated at $25^{\circ} \mathrm{C}$ for $40 \mathrm{~min}$. Absorbance is then read at $405 \mathrm{~nm}$ using a microplate reader, and the percentage of inhibition is calculated with Eq. 2:

Enzyme Inhibition $(\%)=\left[\left(\frac{\mathrm{A}_{\text {control }}-\mathrm{A}_{\text {test sample }}}{\mathrm{A}_{\text {control }}}\right)\right] \times 100$

Where $A_{\text {control }}$ is the absorbance of the buffer, elastase, and solvent, and $A_{\text {test sample }}$ is the absorbance of the buffer, elastase, and extract or elafin/N-methoxysuccinyl-Ala-Ala-Pro-Chloro. 


\section{Hyaluronidase activity}

There are different methods to evaluate hyaluronidase activity [59], which include the classical turbidimetric [60,61], viscometric [62], and colorimetric [63] methods and the more modern spectrophotometric [64-66], fluorogenic [67], radiometric [68], and agarose plate-based [69-70] methods in addition to an ELISA-like method [71-73], high-performance liquid chromatography [74], and zymography [75], among others. The fluorimetric method, which is based on the Morgan-Elson reaction [76] and was first modified by Reissig et al. [77], then by Takahashi et al. [59], is among the most practical and commonly used assays. The procedure is as follows: $25 \mu \mathrm{L}$ of calcium chloride $(12.5 \mathrm{mM})$, $12.5 \mu \mathrm{L}$ of the test sample $(2.8 \mathrm{mg} / \mathrm{mL})$, and hyaluronidase $(1.5 \mathrm{mg} / \mathrm{mL})$ are placed into a $2-\mathrm{mL}$ test tube. The blank control contains $25 \mu \mathrm{L}$ of distilled water, the negative control $12.5 \mu \mathrm{L}$ of distilled water, the positive control $12.5 \mu \mathrm{L}$ of aurothiomalate $(2.8 \mathrm{mg} / \mathrm{mL})$, and the solvent control $12.5 \mu \mathrm{L}$ of the solvent used for dissolution of the extracts. To all tubes, except the blank control, $12.5 \mu \mathrm{L}$ of the enzyme was added. The tubes were then incubated in a water bath at $37^{\circ} \mathrm{C}$ for $20 \mathrm{~min}$. Afterward, $100 \mu \mathrm{L}$ of the substrate $\mathrm{HA}(1 \mathrm{mg} / \mathrm{mL}$ in $0.1 \mathrm{M}$ acetate buffer; $\mathrm{pH}$ 3.5) was added and the tube was incubated for an additional $40 \mathrm{~min}$. Then $25 \mu \mathrm{L}$ of $\mathrm{KBO}_{2}(0.8 \mathrm{M})$ was added to all tubes, which were placed in a water bath at $100^{\circ} \mathrm{C}$ for $3 \mathrm{~min}$. After cooling to room temperature $\left(25^{\circ} \mathrm{C}\right), 800 \mu \mathrm{L}$ of DMAB $(4 \mathrm{~g}$ of DMAB in $40 \mathrm{~mL}$ of acetic acid and $5 \mathrm{~mL}$ of $10 \mathrm{~N} \mathrm{HCl}$ ) was added and the tubes were incubated for 20 min. Afterward, the contents of the tubes were transferred to the wells of a 48-well plate. Fluorescence was detected using a spectrophotometer at an excitation wavelength of $545 \mathrm{~nm}$ and an emission wavelength of $612 \mathrm{~nm}$. The percentage of inhibition was calculated using Eq. 2, where $A_{\text {control }}$ was the absorbance of the buffer, hyaluronidase, and the solvent and $A_{\text {sample }}$ was the absorbance of the buffer, hyaluronidase, and extract or sodium aurothiomalate $[16,59]$.

\section{Anti-acne}

Acne vulgaris is a chronic inflammatory skin disease affecting approximately $85 \%$ of the population at some point in life, typically starting at the ages of $12-14 y$ [78-80]. It is characterized by the presence of comedones, papules, cysts, and nodules [78-81]. While the condition is not life threatening, it causes significant psychological morbidity due to scaring and disfigurement if left untreated [79]. Typically, acne affects the skin of the face, trunk, and upper arms [82]. The localized placement of the condition allows for the use of topical treatments that reduce or eliminate the need for oral drugs [82]. Acne is caused by multiple factors, including androgen-mediated stimulation of sebaceous gland activity, follicular hyperkeratinization, hormonal imbalance, and inflammation caused by stimulation of the innate immune system via several pathways, including external bacterial infection. Propionibacterium acnes and Staphylococcus epidermidis are the major bacterial causes of acne [80,83-85]. According to the study by Han et al. [86], the crucial steps in the control of acne are avoidance of bacterial colonization and inflammation of the pilosebaceous units. Therefore, tests employed for the discovery of ingredients with potential anti-acne activities rely on the antibacterial and anti-inflammatory properties of the test substance.

\section{Agar disk-diffusion method}

The agar disk-diffusion method, which was developed in 1940, is currently the most commonly used test to determine antimicrobial activity $[87,88]$ and is the official method for routine susceptibility testing of cultures of either patient isolates or of samples acquired from the ATCC. In this procedure, agar plates are inoculated with a standardized inoculum of the test microorganism, such as P. acnes (ATCC 6919), S. epidermidis (ATCC 12228), or Staphylococcus aureus (ATCC 25913) in the case of anti-acne testing. Briefly, sterilized filter paper disks, approximately $6 \mathrm{~mm}$ in diameter, are loaded with $20 \mu \mathrm{L}$ of the test substance at an established concentration and subsequently are placed on an inoculated plate at an appropriate distance. Positive controls are confirmed antimicrobials against the test microorganisms, such as triclosan at $5 \mathrm{mg} / \mathrm{mL}$, which has antimicrobial activity against acnecausing bacteria $[89,90]$. As a negative control, $20 \mu \mathrm{L}$ of the solvent used for the preparation of the extract are used. The Petri dish is then incubated under appropriate conditions. The test substance diffuses into the agar and active extracts inhibit bacterial germination and growth. To assess the antibacterial capacity of the samples, the diameters of the bacterial growth inhibition zones surrounding each paper disk are measured [88,91].

\section{Minimum inhibitory concentration}

Once the antimicrobial activity of the plant extracts had been confirmed, the lowest concentration of the extract to inhibit bacterial growth is measured as the minimum inhibitory concentration with the use of the following micro-scale method. The well of each column (1-12) of a 96-well plate is filled with $50 \mu \mathrm{L}$ of sterilized nutrient broth (except for the first well of each column). Then $50 \mu \mathrm{L}$ of plant extract at the appropriate concentration (similar to that employed in the agar diffusion test) is added to the first well of columns 4-12 (each extract in triplicate), which is serially diluted in the following 7 consecutive wells of the columns $(50 \mu \mathrm{L})$, while discarding $50 \mu \mathrm{L}$ of the last wells of each column. Next, $50 \mu \mathrm{L}$ of sterilized nutrient broth and $50 \mu \mathrm{L}$ of the bacterial inoculum $\left(10^{9} \mathrm{CFU} / \mathrm{mL}\right)$ are added to each well to a final volume of $150 \mu \mathrm{L}$. The first 3 wells served as controls. The first well is the positive control that contained an anti-acne drug, such as isotretinoin $(1 \mathrm{mg} / \mathrm{mL})$, which is serially diluted as with the plant extracts. The wells of the second column, as a negative control, contained $50 \mu \mathrm{L}$ of the solvent, $50 \mu \mathrm{L}$ of the bacteria inoculum, and $50 \mu \mathrm{L}$ of nutrient broth. Finally, the third column serves as a sterility control, where the wells contained only the nutrient broth $(150 \mu \mathrm{L})$. The plates are then incubated at $37^{\circ} \mathrm{C}$ for $24 \mathrm{~h}$. After incubation, the indicator dye 2-(4-iodophenyl)-3-(4-nitrophenyl)-5-phenyl$2 \mathrm{H}$-tetrazolium is added to each well, which indicated bacterial growth by a red-pink color, while growth inhibition is indicated by the lack of color change $[85,92]$.

\section{Anti-inflammatory activity}

The anti-inflammatory capability of the extracts can be assessed by measuring the production of inflammatory cytokines by THP1 cells (ATCC TIB-202). First, the cells are seeded in the wells of 24-well plates at a concentration of $1 \times 10^{6}$ cells/well. Then the wells are inoculated with $P$. acnes together with the sample at the appropriate concentrations. Dexamethasone at $1 \times 10^{-5} \mathrm{M}$ is used 
as a positive control. After $24 \mathrm{~h}$ of culture, levels of tumor necrosis factor alpha, interleukin (IL)-1B, IL-6, and IL-8 are measured by flow cytometry and with the use of the BD Cytometric Bead Array Human Inflammatory Cytokines Kit (BD Biosciences) [91, 93].

\section{Solar protection}

Solar UV radiation is composed of 3 different UV bands: UVA (315-400 nm), UVB (280-315 nm), and UVC (<280 nm) [94-98]. Human health is affected both positively and negatively by UV radiation. On the positive side, the principal effects are UVB-mediated production of vitamin $\mathrm{D}$ in the skin, improvement of some dermatological conditions, including psoriasis, vitiligo, and atopic dermatitis, and mood improvement due to the release of endorphins [99-101]. By contrast, the negative effects of UV radiation are responsible for a variety of acute and chronic skin problems. Acute responses include sunburn and erythema, while chronic ailments consist of photoaging and photo-carcinogenesis [102]. In fact, UV light is considered the main etiological agent of a large number of skin cancers, sunburn, and oxidative stress [101]. Topically applied sunscreens can be used to prevent damage to the skin caused by exposure to UV light [102-105]. Active ingredients in sunscreens, referred as UV filters, act in different ways either by absorbing UV radiation (organic-based compounds) or by scattering and reflecting UV radiation (inorganic molecules) [102, 106, 107]. Some studies have demonstrated that the combination of the 2 usually results in better UV protection capabilities of the final product $[102,108,109]$. The efficacy of a sunscreen is measured as the SPF, a term coined by Greiter in 1970 [110], with a higher SPF indicating stronger photoprotective activity [101]. Hence, it is important to note that the value represents an evaluation of protection primarily against UVA- 2 and UVB radiation [ 97 , $98,111-113]$. SPF is expressed as the UV energy required to produce a MED on protected skin divided by the UV energy required to produce a MED on unprotected skin. MED is the lowest time interval or dosage of UV light irradiation that is sufficient to produce a minimally perceptible erythema (skin reddening and inflammation) [98].

\section{SPF measurement}

The only method to measure the efficacy of a sunscreen expressed as SPF that is recognized by the International Organization for Standardization is ISO 244444:2010, an in vivo method that involves $10-20$ human volunteers $[98,101]$. Nevertheless, it is recommended that the in vivo method be preceded by in vitro measurements during the first stages of the development of active ingredients. One of the most commonly used in vitro assays is the Diffey-Robson method $[101,114]$. The FDA recommends a modified version of this method for in vitro SPF testing [102]. The test compares SPF values of preparations of plant extracts with emulsions containing the same proportion of free sunscreens with the use of the SPF-290S computer-controlled analyzer. Briefly, a surgical patch of Transpore tape with an area of $50 \mathrm{~cm}^{2}$ is used as the substrate for the experiment. Normally, $2 \mathrm{mg} / \mathrm{cm}^{2}$ of each test sample is distributed on the substrate surface with a syringe, and a gloved hand is used to stratify the sample with longitudinal movements back and forth. Then transmittance is measured at 6 different points and the results are expressed as aver- age values. To calculate the SPF as an indicator of the UVA/UVB protective property of the test preparation, a calculation is made from the monochromatic protection factor, the solar irradiance, and the erythemal constants according to the Eq. 3:

$S P F=\sum_{290}^{400} E_{\lambda} B_{\lambda} / \sum_{290}^{400} E_{\lambda} B_{\lambda} / M F_{\lambda}$

Where $\mathrm{MPF}_{\lambda}$ is the mean monochromatic protection factor, $\mathrm{E}_{\lambda}$ is the spectral irradiance of terrestrial sunlight under controlled conditions, and $B_{\lambda}$ is the the erythemal effectiveness. The defined condition for $E_{\lambda}$ is the midday midsummer sunlight at $40^{\circ} \mathrm{C} \mathrm{N}$ with a solar zenith angle of $20^{\circ}$ [102]. Some studies have evaluated SPF in vitro using the models proposed in the study by Gharavi et al. [115] or that by Mansur et al. [116].

\section{UVA-PF}

Although useful, SPF is an imperfect measure of skin damage, since UVA light does not primarily cause skin reddening or pain but rather produces invisible damage and skin aging. The UVA-PF can be determined by in vivo or in vitro methods. One assay is persistent pigment darkening, a Japanese in vivo method that is very similar to the SPF test, except that instead of reddening, tanning of the skin is measured. ISO 24443:2012 is an in vitro version of the UVA-PF [101]. Other substitutes for in vivo testing have been suggested with the use of cells and regenerated tissues [117, 118] or with the use of animals [101,119-121]. A recent article in the study by Aparecida-Figueiredo et al. [98] assessed the protective efficacy of sunscreen products using a neonatal cell culture of human dermal fibroblasts by evaluating calcineurin depletion induced by UVA radiation. The method consists of determining calcineurin enzyme activity after irradiation in the absence and presence of sunscreen products. Lysates of neonatal human dermal fibroblasts are exposed to $24 \mathrm{~J} / \mathrm{cm}^{2}$ of UVA radiations in the presence or absence of the sunscreen preparations. The sunscreen products are applied on quartz slides to prevent interaction with the cell lysates so that it is possible to evaluate the UV absorption potential of the sunscreen $[113,122-125]$. The photoprotective formulations are spread on the quartz slides at a concentration of $2 \mathrm{mg} / \mathrm{cm}^{2}$ above each well. After irradiation, the lysates are diluted and processed, and then calcineurin activity is determined as described by Aparecida-Figueiredo et al. [98].

\section{Skin whitening}

Melanin, the principal molecular determinant of skin color, provides skin protection by limiting the absorption of UV radiation by approximately $50-75 \%$ and scavenging reactive oxygen species $[17,126,127]$. In humans, the biosynthesis of melanin is performed inside melanocytes, a type of cell that contains the enzyme tyrosinase [128]. Tyrosinase catalyzes 2 different reactions: the hydroxylation of monophenols to o-diphenols (monophenolase activity) and the oxidation of o-diphenols to o-quinones (diphenolase activity), which are transformed into melanin by a series of nonenzymatic reactions $[128,129]$. Melanogenesis, the synthesis of melanin pigments, is stimulated by exogenous UV light $[128,130,131]$. However, overproduction of melanin may cause hyperpigmentation of the skin. Some conditions caused by 
localized hyperpigmentation in humans include lentigo, nevus, ephelis, a post-inflammatory state, and melanoma in pregnancy $[17,128,132]$. Tyrosinase inhibitors are often employed in cosmeceutical preparations as whitening agents for the treatment of pigmentary disorders $[17,128]$.

\section{Tyrosinase inhibition assay}

A tyrosinase inhibition assay can be performed to measure the whitening capability of the active ingredients of cosmeceutical preparations. The following is a description of the procedure as reported by Chiari et al. [133] and adapted by Liyanaarachchi et al. [17]. The method uses L-DOPA as the enzyme substrate. Briefly, $20 \mu \mathrm{L}$ of various concentrations $(10-50 \mu \mathrm{g} / \mathrm{mL})$ of the test substances (plant extracts or other potentially active ingredients), mushroom tyrosinase aqueous solution $(10 \mu \mathrm{L}, 50 \mathrm{U} / \mathrm{mL})$, and phosphate buffer $(\mathrm{pH} 6.8,80 \mu \mathrm{L})$ are mixed and pre-incubated at $37^{\circ} \mathrm{C}$ for $5 \mathrm{~min}$. Then L-DOPA $(90 \mu \mathrm{L}, 2 \mathrm{mg} / \mathrm{mL}$ ) is added and the mixture is incubated at $37^{\circ} \mathrm{C}$ for $20 \mathrm{~min}$. The amount of dopachrome is measured at a wavelength of $475 \mathrm{~nm}$. Kojic acid dissolved in dimethyl sulfoxide is used as a positive control, while phosphate buffer is used as a blank control. The percent of tyrosinase enzyme is calculated using Eq. 2 , where $A_{\text {test sample }}$ is the absorbance of the sample extract and $A_{\text {control }}$ is the absorbance of the assay using the buffer instead of the inhibitor (sample). The half maximal inhibitory concentration can be calculated for test samples with more than $50 \%$ inhibition from the dose-effect curves, at $500 \mu \mathrm{g} / \mathrm{mL}$.

\section{Wound healing}

Wounds are defined as a disruption of the normal anatomical structure and functional integrity of living tissue [134-136]. Wounds can be caused by physical, chemical, or thermal injury [137] and are classified as incisions, lacerations, abrasions, contusions, ulcers, and burns [136]. In response to damage, the tissue undergoes a complicated process of healing, which consists of 3 stages: inflammation, proliferation, and maturation [136]. To facilitate normal wound healing, the use of an appropriate wound therapy and wound care intervention (bandages) is necessary $[138,139]$. Wounds that exhibit impaired healing by failure to progress through the normal stages of healing enter a state of pathologic inflammation and are considered chronic in nature. Such wounds are usually associated with ischemia, diabetes mellitus, venous stasis disease, and pressure. Non-healing or chronic wounds result in great health care costs due to the requirement of extensive treatment $[136,140,141]$. Alternative products that employ plant extracts as active ingredients could alleviate such costs. However, it is important to determine the wound-healing capabilities of potential ingredients.

Wound-healing models can be classified as either in vitro or in vivo. In vitro models are generally simple, rapid, involve minimal ethical considerations, and provide insight into the biochemical and physiological processes induced by the test compound [137, 142]. There are several standardized protocols, including proliferation [143], scratch [144], cell invasion [144], cell viability, proteomic, and genomic assays [139]. On the other hand, in vivo models are used to determine the degree of re-epithelialization, collagenation, neovascularization, and tensile or breaking strength of wounds. These models include excisions, incisions, superficial wounds, dead space, and burn wounds performed on mammalian models, usually those of rabbits or hamsters [137, 142, 145, 146].

\section{In vitro wound healing models}

In vitro cell culture models are classified as monoculture models and co-culture or 3-dimensional cell models. Monoculture models of the epithelium offer a useful platform to study the re-epithelialization process. The cultures consist of keratinocytes (preferably $\mathrm{HaCaT}$ cells, an immortalized human skin cell line [147]), primary keratinocytes, or epidermal stem cells [139,148-151]. The cell line is grown in a monolayer in vitro and is subjected to a number of assays relevant to the wound healing process [139]. Many studies have used the presence of cytokines [138,152-155], growth factors $[148,156-160]$, or the expression of several markers of the ECM $[161,162]$ as standards for the measurement of the wound healing processes [139]. Co-culture cell models more closely resemble the in vivo epithelial structure and consist of cells that are normally in communication during the wound healing process. An example is the model developed in the study by Sato et al. in 1997 [163], which used keratinocytes and fibroblasts in co-culture. The cell-cell interactions of the Sato model showed enhanced wound healing.

A review by Planz et al. [164] describes a number of modern in vitro skin models that could be employed for the assessment of wound healing capabilities of new products. Similarly, a review by Kucharzewski et al. [165] lists novel approaches to in vitro wound healing models using skin stem cells.

Different methods are used in order to introduce wounds on cell cultures. For monolayers, a common way to simulate a scratch wound includes the manual disruption of the intact monolayer using pipette tips, indirect physical exclusion by placing a physical barrier into the wells and other especially designed tools [166]

\section{In vivo wound healing models}

Even though animal skin does not resemble human skin in vivo tests provide important data that can be used to study the complex process involved in wound healing and offer a good platform for the study and testing of new active ingredients [167-168]. Among the most popular animal models used are rodents and rabbits. Rodent skin differs from humans in several ways: first, rodents have a thin epidermis, loose skin adherence, and dense hair which is thought to contribute to accelerate healing $[168,169]$; they lack apocrine and eccrine glands $[168,169]$; rodents also have a subcutaneous panniculus carnus muscle, which promotes rapid wound contraction; and finally, rodents have stronger immune systems $[168,170]$. Nevertheless, their availability, low cost, and small size make them suitable for large-scale studies [168]. Rabbit models, on the other hand, can provide a closer approach to human skin; their cartilage is highly vascularized and can act as a wound bed that forces healing through re-epithelialization and granulation, like humans, rather than contraction $[168,171]$. The principal downside of this model is their high breeding costs $[168,172]$. Still, animal models are currently superior to in vitro models of wound healing and should be considered prior to human testing of potential active ingredients [168]. 
As mentioned above, several in vivo assays can be employed to evaluate the effectiveness or healing potential of possible active ingredients. One of the most commonly used is the excision wound model. This test offers important information on epithelization, the area of wound contraction, and the wound index. Additionally, it can be used to estimate collagen formation (hexosamine) $[173,174]$. Briefly, the test animals (normally rats) are anesthetized using ketamine $\mathrm{HCl}$ at a dose of $80 \mathrm{mg} / \mathrm{kg}$ of body weight via the peritoneal route. Then the hair of the back region of the animals is shaved and an impression is made on the dorsal thoracic region, from which $300 \mathrm{~mm}^{2}$ of skin is removed, using a scalpel and scissors to create a wound with a depth of not more than $2 \mathrm{~mm}$ [175]. To measure the wound area, progressive changes to the damaged tissues can be monitored with a full high-definition camera on predetermined days (e.g., days 2, 4, 8, 12 , and 20) until the wound has healed. The photographs can later be used to calculate the area width in $\mathrm{mm}^{2}$ [176]. The period of epithelization is determined by the time it takes for the scab to drop from the wound, since it is considered the endpoint of complete epithelization [177]. The wound index is measured using the scoring system described in the study by Zaouani et al. [178]. Assessment of hydroxyproline content is used to estimate the amount of collagen, a key marker of wound healing. For hydroxyproline estimation, the protein hydrolysate is prepared as follows: $50 \mathrm{mg}$ of tissue is collected from the wound site and is placed into a glass tube, which has been autoclaved and neutralized to $\mathrm{pH} 7.0$, containing $1.0 \mathrm{~mL}$ of $6 \mathrm{~N}$ hydrochloric acid. Then $1 \mathrm{~mL}$ of the protein hydrolysate is passed to a clean glass tube, while double distilled water is used as a blank control. Afterward, $1 \mathrm{~mL}$ of new copper sulfate solution $0.01 \mathrm{M}$ is added to the test tube, followed by $1 \mathrm{~mL}$ of $2.5 \mathrm{~N}$ sodium hydroxide and $1 \mathrm{~mL}$ of $6 \%(\mathrm{v} / \mathrm{v})$ hydrogen peroxide. The contents are mixed well, and the tube is heated for $5 \mathrm{~min}$ in a water bath at $80^{\circ} \mathrm{C}$ and is then immediately chilled on ice. Then $4 \mathrm{~mL}$ of $3 \mathrm{~N}$ sulfuric acid is added to the tube followed by agitation. Later, $2 \mathrm{~mL}$ of Ehrlich reagent is added to the test tube, which is then incubated at $70^{\circ} \mathrm{C}$ for $15 \mathrm{~min}$ in a water bath [179]. Afterward, the optical density is measured at a wavelength of $540 \mathrm{~nm}$ using a colorimeter. Finally, the animals are euthanized and the tissue is excised from the wound site for histopathological analysis. The tissue samples are separately stored in conservation solution for microscopic examination [180].

\section{In Vitro Cell Culture Tests for Advanced Cosmeceutical Applications}

As mentioned above, fibroblasts are commonly found in the connective tissue of numerous organs, including the skin, uterus, and gastrointestinal tract, among others. Fibroblasts create ECMs through the secretion of fibrous proteins and ground substances to improve the strength, form, and adhesion capabilities of the structural support of animal organs. The size of fibroblasts vary depending on performance, as active fibroblasts are larger and known to produce modified versions of commonly known proteins, such as collagen, elastin, reticular fibers, and fibronectin [181].
Fibroblasts are employed to test plant-derived cosmeceutical active ingredients in vitro [182]. An in vitro assay allows for the study of skin models as well as dermal toxicology and the efficacy of products. Some in vitro tests using cell cultures are used to assess the anti-aging and detoxification properties of cosmeceuticals by measuring cell proliferation, the oxidative stress response, DNA damage, and collagen formation. In addition, sun protection, skin whitening, and pigmentation are also studied with in vitro skin models. Hence, in vitro cell culture testing is a crucial tool for the development of cosmeceuticals [181]. The following sections discuss the most important aspects of this technology for the development of cosmeceuticals.

\section{In vitro cell culture of fibroblasts for commercial cosmetics testing}

In vitro tests are used to assess the safety of both the ingredients and final cosmeceutical products as well as for justification of efficiency claims. Currently, in vitro tests are mostly employed for safety assessment due to the consumer's desire for "cruelty-free" products [6], while in vivo tests, which involve volunteers, are used to assess efficacy. However, the use of in vitro tests for validation of cosmeceutical claims provides certain advantages, including safety, during the early phases of new product development while offering quicker results and a more cost-effective experimental setting that allows for formulation and screening of ingredient characteristics within ranges that would not be feasible with volunteers [183].

Skin fibroblasts are spindle-shaped cells with long cytoplasmic prolongations derived from multipotent mesenchymal cells, which are closely linked to fibers responsible for dermal architecture and resilience. Additionally, dermal fibroblasts synthesize various growth factors and cytokines that are important in the regeneration processes [183]. Fibroblasts are also suitable for testing the effect of natural compounds on cellular senescence and also the ability of natural compounds to protect from unfavorable environmental conditions [184,185]. Furthermore, fibroblasts stimulate keratinocyte proliferation and reduce some of the most common signs of skin aging, such as wrinkle formation, elastosis, and loss of skin tone. [186]. The following paragraph describes common techniques to test the characteristics of cultured fibroblasts.

Cultures of human fibroblasts are generally established using a cell line from ATTC. Briefly, the cells are cultured in DMEM supplemented with $10 \%(\mathrm{v} / \mathrm{v})$ fetal bovine serum and $1 \%(\mathrm{v} / \mathrm{v})$ antibiotic solution (penicillin or streptomycin) at $37^{\circ} \mathrm{C}$ with an atmosphere of $5 \% \mathrm{CO}_{2} / 95 \%$ air. The cells are subcultured by trypsinization while changing the culture medium every $2-3 \mathrm{~d}$. Cell proliferation is usually assessed using the Mosmann method [187], which is a colorimetric assay based on the reduction of the yellow tetrazolium salt MTT by living cells. In the presence of mitochondrial succinate dehydrogenase found in living cells, the tetrazolium ring of MTT is reduced and forms a violet product, formazan. Thus, the yellow solution becomes purple and the intensity of the coloration is proportional to the number of living cells. Cell proliferation is a desirable effect of plant-derived compounds in cosmeceuticals. For the test, cells at a concentration of $5 \times 10^{4}$ cells $/ \mathrm{mL}$ in $100 \mu \mathrm{L}$ of complete culture medium are seeded into the wells of a 96-well 
plate, which is then incubated under the same conditions as stated above for $24 \mathrm{~h}$. The medium is then removed, and $100 \mu \mathrm{L}$ of the samples (potential cosmeceutical ingredient) prepared in DMEM containing $1 \%(\mathrm{v} / \mathrm{v})$ antibiotic solution or negative control (DMEM containing $1 \%[\mathrm{v} / \mathrm{v}]$ antibiotic solution without sample) is added into the wells. After $48 \mathrm{~h}, 25 \mu \mathrm{L}$ of MTT (5\% w/v in phosphate-buffered saline) is added to each well and the plates are incubated at $37^{\circ} \mathrm{C}$ for $4 \mathrm{~h}$. Afterward, the medium is removed and $200 \mu \mathrm{L}$ of dimethyl sulfoxide is added to the wells and the plate is incubated for $10 \mathrm{~min}$. Following incubation, absorbance is read at $550 \mathrm{~nm}$ using a microplate reader [188]. Cell cytotoxicity can be determined using the sulforhodamine B assay. Briefly, cells $\left(1 \times 10^{4}\right.$ cells/well) are seeded into the wells of a 96 -well plate and the plate is incubated for $24 \mathrm{~h}$. Afterward, the cells are treated with different concentrations of the samples for $72 \mathrm{~h}$. The adherent cells are fixed, washed, and dyed, and then the absorbance is measured at $540 \mathrm{~nm}$. The viability of the treated cells is compared with that of the control cells treated with absolute ethanol [189191]. To determine the antioxidant activity of the proposed active ingredients, the following process can be employed. First, fibroblasts are incubated for $48 \mathrm{~h}$ before treatment. Then the culture media is replaced with different concentrations of the test samples and the solvents (absolute ethanol) are dissolved in culture media for $24 \mathrm{~h}$. Then the media is replaced with fresh culture media containing $150 \mu \mathrm{M} \mathrm{H}_{2} \mathrm{O}_{2}$ and the plate is incubated for an additional $3 \mathrm{~h}$. The cells are then fixed, washed, dyed with sulforhodamine $\mathrm{B}$, and solubilized with $10 \mathrm{mM}\left(\mathrm{HOCH}_{2}\right)_{3} \mathrm{CNH}_{2}$. Finally, absorbance at $540 \mathrm{~nm}$ is measured and cell viability is calculated [189-191]. In order to assess the anti-aging capabilities of the active compounds, collagen production and HA quantification can be performed. For collagen production analysis, dermal fibroblasts at a density of $5 \times 10^{4}$ cells/wells are seeded into the wells of 24-well culture plates in complete culture media. After $24 \mathrm{~h}$, the medium is removed and $2 \mathrm{~mL}$ of either the sample, negative, or positive control in DMEM containing $1 \%(\mathrm{v} / \mathrm{v})$ antibiotic solution is added to each well. The plates are then incubated at $37^{\circ} \mathrm{C}$ for $48 \mathrm{~h}$ and collagen production is measured using the Sirius red staining procedure. With this method, the medium is removed and the cells are washed twice with phosphate-buffered saline and then fixed for $1 \mathrm{~h}$ with $1 \mathrm{~mL}$ of Bouin's solution at room temperature. After fixation, the Bouin's solution is removed and the cells are washed twice with distilled water and then stained with $1 \mathrm{~mL}$ of Sirius red solution $(0.5 \mathrm{~g}$ of Sirius red $80 \mathrm{in} 500 \mathrm{~mL}$ of a saturated aqueous solution of picric acid) for $1 \mathrm{~h}$ while shaking at room temperature. Samples are washed successively with distilled water and $0.01 \mathrm{M} \mathrm{HCl}$ to remove unbound dye. Finally, the bound dye is solubilized in $500 \mu \mathrm{L}$ of $0.1 \mathrm{M} \mathrm{NaOH}$ for $1 \mathrm{~h}$ while shaking and absorbance is read at $550 \mathrm{~nm}$ [188]. Lastly, for HA quantification, an ELISA-like HA test plate can be employed following the instructions of the manufacturer (e.g., R\&D Systems).

\section{In vitro cell culture for skin penetrability}

The skin is the primary entrance point for cosmeceuticals, even though one of its principal functions is to act as a barrier to protect the body from the outside environment, effectively preventing large molecules from entering the body. The former presents a challenge for every cosmeceutical formulation, since, in order to target the desired pharmacological and cosmetic responses, the active metabolites must penetrate the skin [182].

The evaluation of percutaneous permeation of molecules is a key step in the testing of dermal and transdermal delivery systems. If the drugs are intended for delivery to humans, the most appropriate setting for assessment is an in vivo human model. However, human experimentation may not be possible because of ethical, practical, and economic reasons, particularly in the early phases of development [192].

The most relevant model for the evaluation of in vitro skin absorption of drugs is human skin excised from cadavers or obtained from plastic surgeries. However, the availability of human skin is limited; therefore, animal models are often employed. In all cases, it is important to perform in vitro screening of drug permeation from different formulations and to identify factors that increase the transdermal flux of drugs to predict the in vivo behavior of different drug delivery systems [193].

Full-thickness skin or dermatome tissues have been used for in vitro permeation assays. In vitro methods enable precise control of experimental variables with use of the simplest protocols. However, in vitro assays cannot fully reproduce the complexity of biological systems; thus, in vivo evaluations are recommended to validate the results and, if possible, to establish an in vivo-in vitro correlation [193].

Most tests are physical experiments that use membranes, which are either mammalian or synthetic in nature, across which the permeation of a chemical is measured experimentally [194]. A timeline of the in vitro cell cultures used for skin permeability tests during the past decade is presented in $>$ Table 3 . The skin parallel artificial membrane permeability assay provides a suitable platform as a fast, cost-efficient, and high throughput technology. This assay also employs a 96-well plate that contains an artificial membrane, mimicking the properties of stratum corneum in vitro [205]. This modification of the original method comprises an acceptor plate composed of magnetic stirrers, an artificial membrane, as previously stated, and a patch, all of which are placed over a reservoir (i.e., plate holder) [205].

In vivo tests often present a lack of correlation in the permeation capabilities of molecules across from different application sites in the same animal model due to variations in skin thickness. According to Netzlaff et al. [206], the amount of free fatty acids and triglycerides and the density of hair follicles are important factors causing differences between the skin barriers among species [207]. Rodent skin is typically employed in percutaneous permeation studies, with rat skin presenting more structural similarities to human skin; nevertheless, rodent skin, except rat skin, generally has higher permeation rates than human skin [207209].

\section{Perspectives in Cosmeceutical Development}

Nowadays, the public has become more aware of the importance of skin care and professionals are often consulted to obtain recommendations and make better selections of appropriate products. A cross-sectional survey of dermatology residents and der- 
- Table 3 Timeline of the advancements on in vitro cell culture tests for skin permeability.

\begin{tabular}{|c|c|c|c|}
\hline Model & Testing & Results & Reference \\
\hline $\begin{array}{l}\text { Human living skin } \\
\text { equivalent models }\end{array}$ & $\begin{array}{l}\text { Disodium isostearyl 2-O-L-ascorbyl phosphate } \\
\text { is evaluated as a topical prodrug of amphiphilic } \\
\text { vitamin C }\end{array}$ & $\begin{array}{l}\text { Advantageous as a readily available source } \\
\text { for skin care applications }\end{array}$ & [195] \\
\hline $\begin{array}{l}\text { Human skin equivalence } \\
\text { in vitro }\end{array}$ & $\begin{array}{l}\text { Combinations of additives for development } \\
\text { of in vitro test }\end{array}$ & $\begin{array}{l}\text { A pronounced effect on the permeability } \\
\text { barrier }\end{array}$ & [196] \\
\hline $\begin{array}{l}\text { Cultured skin cells and } \\
\text { snap freezing }\end{array}$ & To determine the barrier function of skin & A modified barrier dye penetration assay & [197] \\
\hline Skin membrane & Passive drug permeation & $\begin{array}{l}\text { Mechanistic interpretation of permeability } \\
\text { beyond their predictive abilities }\end{array}$ & [198] \\
\hline Cultured T-cells & $\begin{array}{l}\text { DNA vaccination in the skin using } \\
\text { microneedles }\end{array}$ & Induces higher humoral and cellular immune & [199] \\
\hline In vitro epidermis & $\begin{array}{l}\text { Regulations on the production of fatty acids } \\
\text { Metabolism and permeability }\end{array}$ & $\begin{array}{l}\text { Site where regulations on the production of } \\
\text { fatty acids with more than } 26 \text { carbons occur; } \\
\text { the barrier capabilities of its permeability are } \\
\text { kept by extracellular lipid lamellae. }\end{array}$ & [200] \\
\hline $\begin{array}{l}\text { A human skin model } \\
\text { with cultured cells }\end{array}$ & Synthesized valiolamine derivatives & $\begin{array}{l}\mathrm{N}-2 \text { (-hydroxycyclohexyl) valioamine shows } \\
\text { a stronger inhibitory effect on melanin pro- } \\
\text { duction voglibose }\end{array}$ & [201] \\
\hline Dermal membrane & Microneedles of a novel copper peptide & $\begin{array}{l}\text { Ability to deliver other peptides or cofactors } \\
\text { across the dermal membrane }\end{array}$ & [202] \\
\hline Dermal cells & $\begin{array}{l}\text { nanomicelles with high-pressure homogeni- } \\
\text { zation to raise skin permeability without irrita- } \\
\text { tion }\end{array}$ & $\begin{array}{l}\text { It shows potential as a transdermal delivery } \\
\text { system, specifically in cases respecting } \\
\text { hyperpigmentation. }\end{array}$ & [203] \\
\hline Human kidney cells & $\begin{array}{l}\text { molecular mechanisms of the skin } \\
\text { permeability barrier }\end{array}$ & $\begin{array}{l}\text { Phospholipase domain-containing protein } 1 \\
\text { is directly involved in acylceramide synthesis } \\
\text { as a transacylase }\end{array}$ & [204] \\
\hline
\end{tabular}

matology faculty members performed in 2015 found that dermatology residents feel that education on these products should be included in residency training [210]. Recognition by the medical community of the variety and functionality of cosmeceutical products available on the market would bring more attention to the industry and, if the claims purported by the products are substantiated by tests like the ones mentioned above, this could lead to the validation of cosmeceuticals as a separate category of products from cosmetics.

Recent studies have shown that antioxidant-rich plant extracts can have dual proposes in a cosmeceutical formulation, apart from the traditional health benefits like anti-aging, anti-inflammatory, and antimicrobial activities, but can also function as preservatives by preventing the oxidation of oils present in cosmeceutical products. Another new trend in cosmeceutical development is the use of delivery systems, such as liposomes, microsomes, transferosomes, lipid nanoparticles, polymeric microparticles, and nanoparticles, to facilitate penetration of the skin barrier by the active ingredients to reach appropriate sites [211].

Awareness of the ecological crisis currently afflicting our planet has resulted in a surge of consumer concerns with the environmental impact of the development, manufacturing practices, and quality control procedures of the cosmetics industry. The industry response has been to create new green cosmetic products and the implementation of new environmentally friendly analytical tools, ingredients, and processes. The most polluting step in cosme- ceutical development from natural sources is the extraction of active ingredients. New methods include the use of less polluting solvents or solvent-free processes, like microwave irradiation [211-213].

Finally, as mentioned above, new regulations, specifically in the European Union, have restricted the use of in vivo testing to assess the safety of cosmetic ingredients, which has resulted in the creation of new in vitro methods [38]. In the coming years, we expect emerging countries in South America, Asia, and Africa to implement more such regulations.

\section{Conclusions}

The cosmeceutical industry has continued to grow rapidly, and trends in the marketplace have highlighted the demand for new "natural," "green," and "cruelty-free" products. With this in mind, the discovery of new active ingredients from plants and other organisms has surged. However, the lack of industrial regulations, especially product claims, could lead to consumer dissatisfaction and to subsequent decreased sales. In this regard, the use of tests, especially in vitro methods, to validate product claims would be very valuable to recreate physiological conditions on a smaller and simpler scale. Due to the changing regulations for the safety assessment of cosmetics, it is expected that new in vitro methods for claim authentication and safety appraisal will be developed and validated in the near future. 


\section{Acknowledgements}

This research was supported by grants from the Research Nutriomics Chair Funds and CAT-005 of Tecnologico de Monterrey, Escuela de Ingeniería y Ciencias, as well as Postdoctoral fellowships presented to Dr. Claudia Espinosa-Leal by CONACyT, Mexico, and Tecnologico de Monterrey.

\section{Conflict of Interest}

The authors have no conflicts of interest to declare.

\section{References}

[1] Gebelin CG. Chemistry and our Life. In: Colin WH. Chemistry and our Life. USA: Graphic World Publishing Services; 1997: 435-456

[2] Dorni AC, Amalraj A, Gopi S, Varma K, Anjana SN. Novel cosmeceuticals from plants - an industry guided review. J Appl Res Med Aromat Plants 2017; 7: 1-26

[3] Sorvino C. Why the $\$ 445$ billion beauty industry is a gold mine for self made women. Forbes. Available at https://www.forbes.com/sites/ chloesorvino/2017/05/18/self-made-women-wealth-beauty-goldmine/\#364fbaa32a3a. Accessed November 13, 2017

[4] Reed RE. The definition of cosmeceuticals. J Cosmet Sci 1964; 13: $103-$ 110

[5] Newburger AE. Cosmeceuticals: myths and misconceptions. Clin Dermatol 2009; 27: 446-452

[6] De Castro ML. Cosmetobolomics as an incipient '-omics' with high analytical involvement. Trends Analyt Chem 2011; 30: 1365-1371

[7] Draelos ZD. Cosmeceuticals: undefined, unclassified, and unregulated. Clin Dermatol 2009; 27: 431-434

[8] Lintner K, Mas-Chamberlin C, Mondon P, Peschard O, Lamy L. Cosmeceuticals and active ingredients. Clin Dermatol 2009; 27: 461-468

[9] U.S. Department of Health and Human Services. Cosmetics "Cosmeceutical". U.S. Food and Drug Administration. Available at https://www. fda.gov/Cosmetics/Labeling/Claims/ucm127064.htm. Accessed July 9, 2018

[10] Espinosa-Leal CA, Puente-Garza CA, García-Lara S. In vitro plant tissue culture: means for production of biological active compounds. Planta 2018; 284: 1-18

[11] Puente-Garza CA, García-Lara S, Gutiérrez-Uribe JA. Enhancement of saponins and flavonols by micropropagation of Agave salmiana. Ind Crops Prod 2017; 105: 225-230

[12] Puente-Garza CA, Meza-Miranda C, Ochoa-Martínez D, García-Lara S. Effect of in vitro drought stress on phenolic acids, flavonols, saponins and antioxidant activity in Agave salmiana. Plant Physiol Biochem 2017; 115: 400-407

[13] Espinosa-Leal C, Treviño-Neávez JF, Garza-Padrón RA, Verde-Star M], Rivas-Morales C, Morales-Rubio ME. Total phenols and anti-radical activity of methanolic extracts from wild and in vitro conditions of Leucophyllum frutescens. Rev Mex Cienc Farm 2015; 46: 52-56

[14] García-Pérez E, Gutiérrez-Uribe AJ, García-Lara S. Luteolin content and antioxidant activity in micropropagated plants of Poliomintha glabrescens (Gray). Plant Cell Tiss Organ Cult 2012; 108: 521-527

[15] Royer M, Prado M, García-Pérez ME, Diouf PN, Stevanovic T. Study of nutraceutical, nutricosmetics and cosmeceutical potentials of polyphenolic bark extracts from Canadian forest species. PharmaNutrition 2013; 1 : 158-167

[16] Ndlovu G, Fouche G, Tselanyane M, Cordier W, Steenkamp V. In vitro determination of the anti-aging potential of four southern African medicinal plants. BMC Complement Altern Med 2013; 13: 304
[17] Liyanaarachchi GD, Samarasekera JK, Mahanama KR, Hemalal KD. Tyrosinase, elastase, hyaluronidase, inhibitory and antioxidant activity of Sri Lankan medicinal plants for novel cosmeceuticals. Ind Crops Prod 2018; 111: 597-605

[18] Wijesinghe WA, Jeon Y]. Biological activities and potential cosmeceutical applications of bioactive components from brown seaweeds: a review. Phytochem Rev 2011; 10: 431-443

[19] Anunciato TP, da Rocha Filho PA. Carotenoids and polyphenols in nutricosmetics, nutraceuticals, and cosmeceuticals. J Cosmet Dermatol 2012; 11: 51-54

[20] Mohamed S, Hashim SN, Rahman HA. Seaweeds: a sustainable functional food for complementary and alternative therapy. Trends Food Sci. Technol 2012; 23: 83-96

[21] Sanjeewa KK, Kim EA, Son KT, Jeon Y]. Bioactive properties and potentials cosmeceutical applications of phlorotannins isolated from brown seaweeds: a review. J Photochem Photobiol B 2016; 162: 100-105

[22] Corinaldesi C, Barone G, Mercellini F, Dell'Anno A, Danovaro R. Marine microbial-derived molecules and their potential use in cosmeceutical and cosmetic products. Mar Drugs 2017; 15: 118

[23] Agrawal S, Adholeya A, Barrow C], Deshmukh SK. Marine fungi: an untapped bioresource for future cosmeceuticals. Phytochem Lett 2018; 23: $15-20$

[24] Jones WP, Kinghorn AD. Extraction of Plant secondary Metabolites. In: Sarker S, Nahar L, eds. Natural Products Isolation: Methods in molecular Biology (Methods and Protocols). New York: Humana Press; 2012: 341366

[25] Sasidharan S, Chen Y, Saravanan D, Sundram KM, Yoga Latha L. Extraction, isolation and characterization of bioactive compounds from plants' extracts. Afr J Tradit Complement Altern Med 2011; 8: 1-10

[26] Khan MK, Abert-Vian M, Fabiano-Tixier AS, Dangles O, Chemat F. Ultrasound-assisted extraction of polyphenols (flavanone glycosides) from orange (Citrus sinensis L.) peel. Food Chem 2010; 119: 851-858

[27] Sharmila G, Nikitha VS, Ilaiyarasi S, Dhivya K, Rajasekar V, Kumar NM Muthukumaran K, Muthukumaran C. Ultrasound assisted extraction of total phenolics from Cassia auriculata leaves and evaluation of its antioxidant activities. Ind Crops Prod 2016; 84: 13-21

[28] Yahya NA, Attan N, Wahab RA. An overview of cosmeceutically relevant plant extracts and strategies for extraction of plant-based bioactive compounds. Food and Bioproducts Processing 2018; 112: 69-85

[29] Ajila CM, Brar SK, Verma M, Tyagi RD, Godbout S, Valero JR. Extraction and analysis of polyphenols: recent trends. Crit Rev Biotechnol 2011; 31: 227-249

[30] Azmir ], Zaidul IS, Rahman MM, Sharif KM, Mohamed A, Sahena F, Jahurul MHA, Ghafoor K, Norulaini NAN, Omar AKM. Techniques for extraction of bioactive compounds from plant materials: a review. J Food Eng 2013; 117: 426-436

[31] Adetunji LR, Adekunle A, Orsat V, Raghavan V. Advances in the pectin production process using novel extraction techniques: a review. Food Hydrocoll 2017; 62: 239-250

[32] Herrero M, Cifuentes A, Ibanez E. Sub- and supercritical fluid extraction of functional ingredients from different natural sources: plants food-byproducts, algae and microalgae: a review. Food Chem 2006; 98: 136148

[33] Gil-Chávez G], Villa JA, Ayala-Zavala JF, Heredia JB, Sepulveda D, Yahia EM, González-Aguilar GA. Technologies for extraction and production of bioactive compounds to be used as nutraceuticals and food ingredients: an overview. Compr Rev Food Sci Food Saf 2013; 12: 5-23

[34] Wang L, Weller C. Recent advances in extraction of nutraceuticals from plants. Trends Food Sci Technol 2006; 17: 300-312

[35] Chemat F, Vian MA, Cravotto G. Green extraction of natural products: concept and principles. Int J Mol Sci 2012; 13: 8615-8627 
[36] Sarker SD, Nahar L. An Introduction to natural Products Isolation. In: Sarker SD, Nahar L, eds. Natural Products Isolation. New York: Springer Science+Business Media; 2012: 1-25

[37] Tanaka M, Misawa E, Yamauchi K, Abe F, Ishizaki C. Effects of plant sterols derived from Aloe vera gel on human dermal fibroblasts in vitro and on skin condition in Japanese women. Clin Cosmet Investig Dermatol 2015; 8: 95-104

[38] Almeida A, Sarmento B, Rodrigues F. Insights on in vitro models for safety and toxicity assessment of cosmetic ingredients. Int J Pharm 2017; 519: 178-185

[39] Vinardell MP, Mitjans M. Alternative methods to animal testing for the safety evaluation of cosmetic ingredients: an overview. Cosmetics 2017; 4: 1-14

[40] OECD. Test No.430: In vitro skin corrosion: transcutaneous electrical resistance test method (TER). OECD Better Policies for Better Lives. Available at http://www.oecd.org/publications/test-no-430-in-vitroskin-corrosion-transcutaneous-electrical-resistance-test-method-ter9789264242739-en.htm. Accessed January 22, 2019

[41] OECD. Test No. 431: In vitro skin corrosion: reconstructed human epidermis (RHE) test method. OECD Better Policies for Better Lives. Available at http://www.oecd.org/env/test-no-431-in-vitro-skin-corrosionreconstructed-human-epidermis-rhe-test-method-9789264264618-en. htm. Accessed January 22, 2019

[42] OECD. Test No. 435: In vitro membrane barrier test method for skin corrosion. OECD Better Policies for Better Lives. Available at http://www. oecd.org/env/test-no-435-in-vitro-membrane-barrier-test-method-forskin-corrosion-9789264242791-en.htm. Accessed January 22, 2019

[43] Raschke C, Elsner P. Skin Aging: a Brief Summary of characteristic Changes. In: Farage MA, Miller KW, Maibach, HI, eds. Textbook of Aging Skin. Berlin: Springer; 2010: 55-65

[44] Chattuwatthana T, Okello E. Anti-collagenase, anti-elastase and antioxidant activities of Pueraria candollei var. mirifica root extract and Coccinia grandis fruit juice extract: an in vitro study. European J Med Plants 2015; 5: 318-327

[45] Thring TS, Hili P, Naughton DP. Anti-collagenase, anti-elastase and antioxidant activities of extracts from 21 plants. BMC Complement Altern Med 2009; 9: 1-11

[46] Mukherjee PK, Maity N, Nema NK, Sarkarm BK. Bioactive compounds from natural resources against skin aging. Phytomedicine 2011; 19 : 64-73

[47] Jenkins G. Molecular mechanisms of skin ageing. Mech Ageing Dev 2002; 123: 801-810

[48] Buckingham EM, Klingelhutz AJ. The role of telomeres in the ageing of human skin. Exp Dermatol 2011; 20: 297-302

[49] Murina AT, Kerisit KG, Boh EE. Mechanisms of skin aging. Cosmet Dermatol 2012; 25: 399-402

[50] Rittie L, Fisher G]. UV-light-induced signal cascades and skin aging. Ageing Res Rev 2002; 1: 705-720

[51] Fulop T, Khalil A, Larbi A. The role of elastin peptides in modulating the immune response in aging and age-related diseases. Pathol Biol 2012; 60: $28-33$

[52] Manuskiatti W, Maibach H. Hyaluronic acid and skin: wound healing and aging. Int J Dermatol 1996 35: 539-544

[53] Hsu MF, Chiang BH. Stimulating effects of Bacillus subtilis natto-fermented Radix astragali on hyaluronic acid production in human skin cells. J Ethnopharmacol 2009; 125: 474-481

[54] Fisher G], Kang S, Varani ], Bata-Csorgo Z, Wan Y, Datta S, Voorhees J]. Mechanisms of photoaging and chronological skin aging. Arch Dermatol 2002; 138: 1462-1470

[55] Pfeifer GP, Besaratinia A. UV wavelength-dependent DNA damage and human non-melanoma and melanoma skin cancer. Photochem Photobiol Sci 2012; 11: 90-97
[56] Prior RL, Wu X, Schaich K. Standardized methods for the determination of antioxidant capacity and phenolics in food and dietary supplements. J Agric Food Chem 2005; 53: 4290-4302

[57] Van Wart HE, Steinbrink DR. A continuous spectrophotometric assay for Clostridium histolyticum collagenase. Anal Biochem 1981; 113: 356-365

[58] Kraunsoe JA, Claridge T, Lowe G. Inhibition of human leukocyte and porcine pancreatic elastase by homologues of bovine pancreatic trypsin inhibitor. Biochemistry 1996; 35: 9090-9096

[59] Takahashi T, Ikegami-Kawai M, Okuda R, Suzuki K. A fluorimetric Morgan-Elson assay method for hyaluronidase activity. Anal Biochem 2003; 322: 257-263

[60] Dorfman A, Ott ML. A turbidimetric method for the assay of hyaluronidase. J Biol Chem 1948; 172: 367-375

[61] Di Ferrante N. Turbidimetric measurement of acid mucopolysaccharides and hyaluronidase activity. J Biol Chem 1956; 220: 303-306

[62] Dorfman A. The kinetics of the enzymatic hydrolysis of hyaluronic acid. J Biol Chem 1948; 172: 377-387

[63] Bonner WM jr., Cantey EY. Colorimetric method for determination of serum hyaluronidase activity. Clin Chim Acta 1966; 13: 746-752

[64] Benchetrit LC, Pahuja SL, Grey ED, Edstrom RD. A sensitive method for the assay of hyaluronidase activity. Anal Biochem 1977; 79: 431-437

[65] Homer KA, Denbow L, Beighton D. Spectrophotometric method for the assay of glycosaminoglycans and glycosaminoglycan-depolymerizing enzymes. Anal Biochem 1993; 214: 435-441

[66] Vercruysse KP, Lauwers AR, Demeester JM. Kinetic investigation of the action of hyaluronidase on hyaluronan using the Morgan-Elson and neocuproine assays. Biochem J 1995; 310: 55-59

[67] Nakamura T, Majima M, Kubo K, Takagaki K, Tamura S, Endo M. Hyaluronidase assay using fluorogenic hyaluronate as a substrate. Anal Biochem 1990; 191: 21-24

[68] Laurent UB, Tengblad A. Determination of hyaluronate in biological samples by a specific radioassay technique. Anal Biochem 1980; 109: 386 394

[69] Richman PG, Baer H. A convenient plate assay for the quantitation of hyaluronidase in Hymenoptera venoms. Anal Biochem 1980; 109: 376381

[70] Tung JS, Mark GE, Hollis GF. A microplate assay for hyaluronidase and hyaluronidase inhibitors. Anal Biochem 1994; 223: 149-152

[71] Stern M, Stern R. An ELISA-like assay for hyaluronidase and hyaluronidase inhibitors. Matrix 1992; 12: 397-403

[72] Delpech B, Bertrand P, Maingonnat C, Girard N, Chauzy C. Enzymelinked hyaluronectin: a unique reagent for hyaluronan assay and tissue location and for hyaluronidase activity detection. Anal Biochem 1995; 229: 35-41

[73] Gregory I, Stern R. A microtiter-based assay for hyaluronidase activity not requiring specialized reagents. Anal Biochem 1997; 251: 263-269

[74] Cramer JA, Bailey LC. A reversed-phase ion-pair high-performance liquid chromatography method for bovine testicular hyaluronidase digests using postcolumn derivatization with 2-cyanoacetamide and ultraviolet detection. Anal Biochem 1991; 196: 183-191

[75] Guntenhöner MW, Pogrel MA, Stern RA. A substrate-gel assay for hyaluronidase activity. Matrix 1992; 12: 388-396

[76] Elson LA, Morgan W. A colorimetric method for the determination of glucosamine and chondrosamine. Biochem J 1933; 27: 1824-1828

[77] Reissig JL, Strominger JL, Leloir LF. A modified colorimetric method for the estimation of N-acetylamino sugars. J Biol Chem 1955; 217: 959966

[78] Gollnick H. Acne and related Disorders. In: Elzouki AY, Harfi HA, Nazer H, Oh W, Stapleton FB, Whitley RJ, eds. Textbook of clinical Pediatrics. Berlin: Springer; 2012: 1447-1466

[79] Mahmood NF, Shipman AR. The age-old problem of acne. Int J Womens Dermatol 2017; 3: 71-76 
[80] Thiboutot DM, Dréno B, Abanmi A, Alexis AF, Araviiskaia E, Barona Cabal MI, Bettoli V, Casintahan F, Chow S, da Costa A, El Ouazzani T, Goh CL, Gollnick HPM, Gomez M, Hayashi N, Herane MI, Honeyman J, Kang S, Kemeny L, Kubba R, Lambert J, Layton AM, Leyden J], López-Estebaranz JL, Noppakun N, Ochsendorf F, Oprica C, Orozco B, Perez M, PiqueroMartin J, See JA, Suh DH, Tan J, Lozada VT, Troielli P, Xiang LF. Practical management of acne for clinicians: an international consensus from the Global Alliance to Improve Outcomes in Acne. J Am Acad Dermatol 2018; 78: S1-S23

[81] Gollnick HP, Bettoli V, Lambert J, Araviiskaia E, Binic I, Dessinioti C, Galadari I, Ganceviciene R, Ilter N, Kaegi M, Kemeny L, López-Estebaranz JL, Massa A, Oprica C, Sinclair W, Szepietowski JC, Dréno B. A consensusbased practical and daily guide for the treatment of acne patients. J Eur Acad Dermatol Venereol 2016; 30: 1480-1490

[82] Toombs EL. Cosmetics in the treatment of acne vulgaris. Dermatol Clin 2005; 23: 575-581

[83] Coenye T, Peeters E, Nelis HJ. Biofilm formation by Propionibacterium acnes is associated with increased resistance to antimicrobial agents and increased production of putative virulence factors. Res Microbiol 2007; 158: 386-392

[84] Thiboutot D, Gollnick H, Bettoli V, Dréno B, Kang S, Layden J], Shalita AR, Lozada VT, Berson D, Finlay A, Goh CL, Herane MI, Kaminsky A, Kubba R, Layton A, Miyachi Y, Perez M, Martin JP, Ramos-E-Silva M, See JA, Shear N, Wolf J jr.; Global Alliance to Improve Outcomes in Acne. New insights into the management of acne: an update from the Global Alliance to Improve Outcomes in Acne Group. J Am Acad Dermatol 2009; 60: S1-S50

[85] Vora J, Srivastava A, Modi H. Antibacterial and antioxidant strategies for acne treatment through plant extracts. Informatics in Medicine Unlocked 2018; 13: 128-132

[86] Han R, Blencke HM, Cheng H, Li C. The antimicrobial effect of CEN1HC-Br against Propionibacterium acnes and its therapeutic and anti-inflammatory effects on acne vulgaris. Peptides 2018; 99: 36-43

[87] Heatley NG. A method for the assay of penicillin. Biochem J 1944; 38 : 61-65

[88] Balouiri M, Sadiki M, Ibnsouda SK. Methods for in vitro evaluating antimicrobial activity: a review. JPA 2016; 6: 71-79

[89] Lee TW, Kim JC, Hwang SJ. Hydrogel patches containing triclosan for acne treatment. Eur J Pharm Biopharm 2003; 56: 407-412

[90] Hoq MI, Ibrahim HR. Potent antimicrobial action of triclosan-lysozyme complex against skin pathogens mediated through drug-targeted delivery mechanism. Eur J Pharm Sci 2011; 42: 130-137

[91] Jeong WY, Kim K. Anti-Propionibacterium acnes and the anti-inflammatory effect of Aloe ferox Miller components. J Herb Med 2017; 9: 53-59

[92] Shah P, Modi HA, Shukla MD, Lahiri SK. Preliminary phytochemical analysis and antibacterial activity of Ganoderma lucidum collected from dang district of Gujarat, India. Int J Curr Microbiol App Sci 2014; 4: 246-255

[93] Tsung-Hsien T, Tzung-Hsun T, Wenhuey W, Po-Jung T. In vitro antimicrobial and anti-inflammatory effects of herbs against Propionibacterium acnes. Food Chem 2010; 119: 964-968

[94] Gilaberte Y, González S. Update on photoprotection. Actas Dermosifiliogr 2010; 101: 659-672

[95] Mouret S, Bogdanowicz P, Haure M], Castex-Rizzi N, Cadet J, Favier A, Douki T. Assessment of the photoprotection properties of sunscreens by chromatographic measurement of DNA damage in skin explants. Photochem Photobiol 2011; 87: 109-116

[96] Schuch AP, Moraes MC, Yagura T, Menck CF. Highly sensitive biological assay for determining the photoprotective efficacy of sunscreen. Environ Sci Technol 2014; 48: 11584-11590

[97] Wang SQ, Xu H, Stanfield JW, Osterwalder U, Herzog B. Comparison of ultraviolet A light protection standards in the United States and European Union through in vitro measurements of commercially available sunscreens. J Am Acad Dermatol 2017; 77: 42-47
[98] Figueiredo SA, de Moraes DC, Vilela FMP, de Faria AN, dos Santos MH, Fonseca MJV. A novel research model for evaluating sunscreen protection in the UV-A1. J Photochem Photobiol B 2018; 178: 61-68

[99] Juzeniene A, Moan J. Beneficial effects of UV radiation other than via vitamin D production. Dermatoendocrinol 2012; 4: 109-117

[100] Wright F, Weller RB. Risks and benefits of UV radiation in older people: more of a friend than a foe? Maturitas 2015; 81: 425-431

[101] Radice M, Manfredini S, Ziosi P, Dissette V, Buso P, Fallacara A, Vertuani S. Herbal extracts, lichens and biomolecules as natural photo-protection alternatives to synthetic UV filters. A systematic review. Fitoterapia 2016; 114: 144-162

[102] Li CC, Lin YT, Chen YT, Sie SF, Chen-Yang YW. Improvement in UV protection retention capability and reduction in skin penetration of benzophenone- 3 with mesoporous silica as drug carrier by encapsulation. Photochem Photobiol B 2015; 148: 277-283

[103] Ullrich SE, Schmitt DA. The role of cytokines in UV-induced systemic immune suppression. J Dermatol Sci 2000; 23: 10-12

[104] Walterscheid JP, Nghiem DX, Ullrich SE. Determining the role of cytokines in UV-induced immunomodulation. Methods 2002; 28: 71-78

[105] Ullrich SE. Mechanisms underlying UV-induced immune suppression. Mutat Res Fundam Mol Mech Mutagen 2005; 571: 185-205

[106] Nick S, Daniele D, Angelo A. Inorganic and organic UV filters: their role and efficacy in sunscreens and suncare products. Inorg Chim Acta 2007; 360: 794-802

[107] Shaath NA. Ultraviolet filters. Photochem Photobiol Sci 2010; 9: 463469

[108] Diffey BL, Tanner PR, Matts PJ, Nash JF. In vitro assessment of the broad-spectrum ultraviolet protection of sunscreen products. J Am Acad Dermatol 2000; 43: 1024-1035

[109] Chen-Yang YW, Chen YT, Li CC, Yu HC, Chuang YC, Su JH, Lin YT. Preparation of UV-filter encapsulated mesoporous silica with high sunscreen ability. Mater Lett 2011; 65: 1060-1062

[110] Greiter F. Sun protection factor-development methods. Parf Kosm 1970; 55: 70-75

[111] Scalka S, dos Reis VMS. Fator de proteção solar: significado e controvérsias. An Bras Dermatol 2011; 86: 507-515

[112] Pelizzo M, Zattra E, Nicolosi P, Peserico A, Garoli D, Alaibac M. In vitro evaluation of sunscreens: an update for the clinicians. ISRN Dermatol 2012; 2012: 1-4

[113] Hibbert SA, Costello P, O'Connor C, Bell M, Griffiths CE, Watson RE, Sherratt MJ. A new in vitro assay to test UVR protection of dermal extracellular matrix components by a flat spectrum sunscreen. J Photochem Photobiol B 2017; 175: 58-64

[114] Diffey BL, Robson JA. A new substrate to measure sunscreen protection factors throughout the ultraviolet spectrum. J Soc Cosmet Chem 1989; 40: 127-133

[115] Gharavi SM, Tavakoli N, Paradakhti A, Baghaei-Zadeh N. Determination of sun protection factor of sunscreens by two different in vitro methods. J Res Med Sci 1999; 2: 53-54

[116] Mansur JS, Breder MN, Mansur MC, Azulay RD. Determinaçãodofactorde proteção solar por espectrofotometria. An Bras Dermatol 1986; 61: 121-124

[117] Huang CC, Wu WB, Fang JY, Chiang HS, Chen SK, Chen YT, Hung CF. Epicatechin-3-gallate, a green tea polyphenol is a potent agent against UVB-induced damage in HaCaT keratinocytes. Molecules 2007; 7: 1845-1858

[118] Santa-Maria C, Revilla E, Miramontes E, Bautista J, García-Martínez A, Romero E, Carballo M, Parrado J. Protection against free radicals (UVB irradiation) of a water-soluble enzymatic extract from rice bran. Study using human keratinocyte mono-layer and reconstructed human epidermis. Food Chem Toxicol 2010; 48: 83-88 
[119] Casagrande R, Georgetti SR, Verri JW, Dorota D], Dos Santos AC, Fonseca MJ. Protective effect of topical formulations containing quercetin against UVB-induced oxidative stress in hairless mice. J Photochem Photobiol B 2006; 84: 21-27

[120] Casagrande R, Georgetti SR, Verri JW, Borin MF, Lopez RF, Fonseca M]. In vitro evaluation of quercetin cutaneous absorption from topical formulations and its functional stability by antioxidant activity. Intern J Pharm 2007; 328: 183-190

[121] Petrova A, Davids LM, Rautenbach F, Marnewick JL. Photoprotection by honeybush extracts, hesperidin and mangiferin against UVB-induced skin damage in SKH-1 mice. J Photochem Photobiol B 2011; 103: 126-139

[122] Botta C, Giorgio CD, Sabatier A, Méo M. Genotoxicity of visible light $(400-800 \mathrm{~nm})$ and photoprotection assessment of ectoin, L-ergothioneine and mannitol and four sunscreens. J Photochem Photobiol B 2008; 91: 24-34

[123] Figueiredo SA, Vilela FM, Silva CA, Cunha TM, dos Santos MH, Fonseca MJ. In vitro and in vivo photoprotective/photochemopreventive potential of Garcinia brasiliensis epicarp extract. J Photochem Photobiol B 2014; 131: 65-73

[124] Martins RM, Siqueira S, Fonseca MJ, Freitas LA. Skin penetration and photoprotection of topical formulations containing benzophenone-3 solid lipid microparticles prepared by the solvent-free spray-congealing technique. J Microencapsul 2014; 31: 644-653

[125] Alves GA, de Souza RO, Rogez H, Masaki H, Fonseca MJ. Cecropia obtuse, an Amazonian ethanolic extract, exhibits photochemoprotective effect in vitro and balances the redox cellular state in response to UV radiation. Ind Crop Prod 2016; 94: 893-902

[126] Parvez S, Kang M, Chung HS, Bae H. Naturally occurring tyrosinase inhibitors: mechanism and applications in skin health: cosmetics and agriculture industries. Phytother Res 2007; 21: 805-816

[127] Tada M, Kohno M, Niwano Y. Scavenging or quenching effect of melanin on superoxide anion and singlet oxygen. J Clin Biochem Nutr 2010; 46: $224-228$

[128] Muddathir AM, Yamauchi K, Batubara I, Mohieldin EA, Mitsunaga T. Anti-tyrosinase, total phenolic content and antioxidant activity of selected Sudanese medicinal plants. S African J Bot 2017; 109: 9-15

[129] Sánchez-Ferrer A, Rodrígez-López J, García-Carmona F. Tyrosinase: a comprehensive review of its mechanism. Biochim Biophys Acta 1995; 1247: 1-11

[130] Bogh MK, Schmedes AV, Philipsen PA, Thieden E, Wulf HC. Vitamin D production after UVB exposure depends on baseline vitamin $D$ and total cholesterol but not on skin pigmentation. J Invest Dermatol 2010; 130: $546-553$

[131] Xie P, Huang L, Zhang C, Ding S, Deng Y, Wang X. Skin-care effects of dandelion leaf extract and stem extract: antioxidant properties, tyrosinase inhibitory and molecular docking simulations. Ind Crops Prod 2018; 111: 238-246

[132] Tomita K, Oda N, Ohbayashi M, Kamei H, Miyaki T, Oki T. A new screening method for melanin biosynthesis inhibitors using Streptomyces bikiniensis. J Antibiot (Tokyo) 1990; 43: 1601-1605

[133] Chiari M, Joray MB, Ruiz G, Palacios SM, Carpinella MC. Tyrosinase inhibitory activity of native plants from Central Argentina: isolation of an active principle from Lithraea molleoides. Food Chem 2010; 120 : $10-14$

[134] Lazarus GS, Cooper DM, Knighton DR, Percoraro RE, Rodeheaver G, Robson MC. Definitions and guidelines for assessment of wounds and evaluation of healing. Wound Repair Regen 1994; 2: 165-170

[135] Strodtbeck F. Physiology of wound healing. Newborn Infant Nurs Rev 2001; 1: 43-45

[136] Jarić S, Kostić O, Mataruga Z, Pavlović D, Pavlović M, Mitrović M, Pavlović P. Traditional wound-healing plants used in the Balkan region (Southeast Europe). J Ethnopharmacol 2018; 211: 311-328
[137] Agyare C, Boakye YD, Bekoe EO, Hensel A, Dapaah SO, Appiah T. Review: African medicinal plants with wound healing properties. J Ethnopharmacol 2016; 177: 85-100

[138] Huang C, Leavitt T, Bayer LR, Orgill DP. Effect of negative pressure wound therapy on wound healing. Curr Probl Surg 2014; 51: 301-331

[139] Vidmar J, Chingwaru C, Chingwaru W. Mammalian cell models to advance our understanding of wound healing: a review. J Surg Res 2017; 210: $269-280$

[140] Mathieu D, Linke JC, Wattel F. Non-healing Wounds. In: Mathieu D, ed. Handbook on hyperbaric Medicine. Netherlands: Springer; 2006: 401427

[141] Menke NB, Ward KR, Witten TM, Bonchev DG, Diegelmann RF. Impaired wound healing. Clin Dermatol 2007; 25: 19-25

[142] Gottrup A, Ågren MS, Karlsmark T. Models for use in wound healing research: a survey focusing on in vitro and in vivo adult soft tissue. Wound Repair Regen 2000; 8: 83-96

[143] Bueno FG, Panizzon GP, Mello EV, Lechtenberg M, Petereit F, de Mello JC, Hensel A. Hydrolyzable tannins from hydroalcoholic extract from Poincianella pluviosa stem bark and its wound-healing properties: phytochemical investigations and influence on in vitro cell physiology of human keratinocytes and dermal fibroblasts. Fitoterapia 2014; 99: 252-260

[144] Justus CR, Leffler N, Ruiz-Echevarria M, Yang LV. In vitro cell migration and invasion assays. J Vis Exp 2014; 752: 10-24

[145] Davidson JM. Animal models for wound repair. Arch Dermatol Res 1998; 290: 1-11

[146] Gal P, Kilik R, Morkry M, Vidinsky B, Vasilenko T, Mozes S, Bobrov N, Tomori Z, Bober J, Lenhardt L. Simple method of open skin wound healing model in corticosteroid-treated and diabetic rats: standardization of semi-quantitative and quantitative histological assessments. Vet Med 2008; 53: 652-659

[147] Boukamp P, Petrussevska RT, Breitkreutz D, Hornung J, Markham J, Fusenig NE. Normal keratinization in a spontaneously immortalized aneuploid human keratinocyte cell line. J Cell Biol 1988; 106: 761-771

[148] Li X, Liang L, Zhao P, Uchida K, Baba H, Huang H, Bai W, Bai L, Zhang M. The effects of adenoviral transfection of the keratinocyte growth factor gene on epidermal stem cells: an in vitro study. Mol Cell 2013; 36: 316-321

[149] Liu M, Saeki K, Matsunobu T, Okuno T, Koga T, Sugimoto Y, Yokoyama C, Nakamizo S, Kabashima K, Narumiya S, Shimizu T, Yokomizo T. 12-Hydroxyheptadecatrienoic acid promotes epidermal wound healing by accelerating keratinocyte migration via the BLT2 receptor. J Exp Med 2014; 211: 1063-1078

[150] Ojeh NO, Navsaria HA. An in vitro skin model to study the effect of mesenchymal stem cells in wound healing and epidermal regeneration. J Biomed Mater Res A 2014; 102: 2785-2792

[151] Skazik C, Amann PM, Heise R, Marquardt Y, Czaja K, Kim A, Rühl R, Kurschat P, Merk HF, Bickers DR, Baron JM. Downregulation of STRA6 expression in epidermal keratinocytes leads to hyperproliferation-associated differentiation in both in vitro and in vivo skin models. J Invest Dermatol 2014; 134: 1579-1588

[152] Mori R, Kondo T, Nishie T, Ohshima T, Asano M. Impairment of skin wound healing in beta-1, 4-galactosyltransferase-deficient mice with reduced leukocyte recruitment. Am J Pathol 2004; 164: 1303-1314

[153] Guo S, Dipietro LA. Factors affecting wound healing. J Dent Res 2010; 89: 219-229

[154] Huebener P, Schwabe RT. Regulation of wound healing and organ fibrosis by toll-like receptors. Biochim Biophys Acta 2012; 1832: 1005-1017

[155] Forbes S], Rosenthal N, Forbes S], Rosenthal N. Preparing the ground for tissue regeneration: from mechanism to therapy. Nat Med 2014; 20: 857-869 
[156] Sturm A, Sudermann T, Schulte KM, Goebell H, Dignass AU. Modulation of intestinal epithelial wound healing in vitro and in vivo by lysophosphatidic acid. Gastroenterology 1999; 117: 368-377

[157] Pawar S, Kartha S, Toback FG. Differential gene expression in migrating renal epithelial cells after wounding. J Cell Physiol 1995; 165: 556-565

[158] Yamamoto M, Yanaga H, Nishina H, Watabe S, Mamba K. Fibrin stimulates the proliferation of human keratinocytes through the autocrine mechanism of transforming growth factor-alpha and epidermal growth factor receptor. Tohoku J Exp Med 2005; 207: 33-40

[159] Kim JY, Suh W. Stem cell therapy for dermal wound healing. Int J Stem Cells 2010; 3: 29-31

[160] Ebihara N, Matsuda A, Nakamura S, Matasuda H, Murakami A. Role of the IL-6 classic- and trans-signaling pathways in corneal sterile inflammation and wound healing. Invest Ophthalmol Vis Sci 2011; 52: 85498557

[161] Thomas DW, Hopkinson I, Hardning KG, Shepherd JP. The pathogenesis of hypertrophic/keloid scarring. Int J Oral Maxillofac Surg 1994; 24: 232-235

[162] Sesia SB, Duhr R, Medeiros da Cunha C, Todorov A, Schaeren S, Padovan E, Spagnoli G, Martin I, Barbero A. Anti-inflammatory/tissue repair macrophages enhance the cartilage-forming capacity of human bone marrow-derived mesenchymal stromal cells. J Cell Physiol 2015; 230: 1258-1269

[163] Sato T, Kirimura Y, Mori Y. The co-culture of dermal fibroblasts with human epidermal keratinocytes induces increased prostaglandin E2 production and cyclooxygenase 2 activity in fibroblasts. J Invest Dermatol 1997; 109: 334-349

[164] Planz V, Lehr CM, Windbergs M. In vitro models for evaluating safety and efficacy of novel technologies for skin drug delivery. J Control Release 2016; 242: 89-104

[165] Kucharzewski M, Rojczyka E, Wilemska-Kucharzewska K, Wilk R, Hudecki J, Los MJ. Novel trends in application of stem cells in skin wound healing. Eur J Pharmacol 2019; 843: 307-315

[166] Planz V, Wang J, Windbergs M. Establishment of a cell-based wound healing assay for bio-relevant testing of wound therapeutics. J Pharmacol Toxicol Methods 2018; 89: 19-25

[167] Trujillo AN, KesI SL, Sherwood J, Wu M, Gould LJ. Demonstration of the rat ischemic skin wound model. J Vis Exp 2015; 1: e52637

[168] Sami DG, Heiba HH, Abdellatif A. Wound healing models: a systematic review of animal and non-animal models. Wound Medicine 2019; 24: $8-17$

[169] Dorsett-Martin WA. Rat models of skin wound healing: a review. Wound Repair Regen 2004; 12: 591-599

[170] Seaton M, Hocking A, Gibran NS. Porcine models of cutaneous wound healing. ILAR J 2015; 56: 127-138

[171] Rittié L. Cellular mechanisms of skin repair in humans and other mammals. J Cell Commun Signal 2016; 10: 103-120

[172] Yao Z, Huang Y, Luo G, Wu J, He W. A biological membrane-based novel excisional wound-splinting model in mice (with video). Burns Trauma 2014; 2: 196-200

[173] Nagar HK, Srivastava AK, Srivastava R, Kurmi ML, Chandel HS, Ranawat MS. Pharmacological investigation of the wound healing activity of Cestrum nocturnum (L.) ointment in Wistar albino rats. J Pharm (Cairo) 2016; 2016: 9249040

[174] Shrivastav A, Mishra AK, Ali SS, Ahmad A, Abuzinadah MF, Khan NA. In vivo models for assessment of wound healing potential: a systematic review. Wound Medicine 2018; 20: 43-53

[175] Kirubanandan S, Bharathi R, Renganathan S. Histological and biochemical evaluation of wound regeneration potential of Terminalia chebula fruits. Asian J Pharm Clin 2016; 9: 228-233

[176] Gowda A, Shanbhag V, Shenoy S, Bangalore ES, Prabhu K, Murthy R, Venumadhav N, Goudapalla P, Narayanareddy M, Shanbhag T. Wound healing property of topical application of ethanolic extract of Michelia champaca flowers in diabetic rats. J Pharmacol Clin Sci 2016; 2: 67-74

[177] Patil MV, Kandhare AD, Bhise SD. Pharmacological evaluation of ethanolic extract of Daucus carota Linn root formulated cream on wound healing using excision and incision wound model. Asia Pac J Trop Biomed 2012; 2: S646-S655

[178] Zaouani M, Bitam A, Baz A, Benali Y, Mahdi MH. In vivo evaluation of wound healing and anti-inflammatory activity of methanolic extract of roots of Centaurea africana (L.) in topical formulation. Asian J Pharm Clin Res 2017; 10: 341-346

[179] Lowry OH, Rosebrough NJ, Farr AL, Randall RJ. Protein measurement with the Folin phenol reagent. J Biol Chem 1951; 193: 265-275

[180] Saha K, Mukherjee PK, Das J, Pal M, Saha BP. Wound healing activity of Leucas lavandulaefolia Rees. J Ethnopharmacol 1997; 56: 139-144

[181] Li M, Zhao Y, Hao H, Han W, Fu X. Theoretical and practical aspects of using fetal fibroblasts for skin regeneration. Ageing Res Rev 2017; 36: 32-41

[182] Taufikurohmah T, Winarni D, Baktir A, Sanjaya GMI, Syahrani A. Histology study: pre-clinic test of nanogold in mus musculus skin, at fibroblast proliferation and collagen biosynthesis. Chemistry and Materials Research 2013; 3: 55-60

[183] Ramata-Stunda A, Boroduskis M, Vorobjeva V, Ancans ]. Cell and tissue culture-based in vitro test systems for evaluation of natural skin care product ingredients. Environ Exp Biol 2013; 11: 159-177

[184] Bae JY, Lim SS, Kim SJ, Choi JS, Park J, Ju SM, Han SJ, Kang IJ, Kang YH. Bog blueberry anthocyanins alleviate photoaging in ultraviolet-B irradiation-induced human dermal fibroblasts. Mol Nutr Food Res 2009; 53: $726-738$

[185] Kim YH, Kim KS, Han CS, Yang HC, Park SH, Ko KI, Lee SH, Kim KH, Lee $\mathrm{NH}$, Kim JM, Son K. Inhibitory effects of natural plants of Jeju Island on elastase and MMP-1 expression. Int J Cosmet Sci 2007; 29: 487-488

[186] Żerańska J, Pasikowska M, Szczepanik B, Mlosek K, Malinowska S, Dębowska RM, Eris I. A study of the activity and effectiveness of recombinant fibroblast growth factor (Q40P/S47I/H93G rFGF-1) in antiaging treatment. Postepy Dermatol Alergol 2016; 33: 28-36

[187] Mosmann T. Rapid colorimetric assay for cellular growth and survival: application to proliferation and cytotoxicity assays. J Immunol Methods 1983; 65: 55-63

[188] Adrien A, Bonnet A, Dufour D, Baudouin S, Maugard T, Bridiau N. Pilot production of ulvans from Ulva sp. and their effects on hyaluronan and collagen production in cultured dermal fibroblasts. Carbohydr Polym 2017; 157: 1306-1314

[189] Chaikul P, Lourith N, Kanlayavattanakul M. Antimelanogenesis and celIular antioxidant activities of rubber (Hevea brasiliensis) seed oil for cosmetics. Ind Crop Prod 2017; 108: 56-62

[190] Lourith N, Kanlayavattanakul M. Ceylon spinach: a promising crop for skin hydrating products. Ind Crop Prod 2017; 105: 24-28

[191] Kanlayavattanakul M, Lourith N, Chaikul P. Biological activity and phytochemical profiles of Dendrobium: a new source for specialty cosmetic materials. Ind Crop Prod 2018; 120: 61-70

[192] Abd E, Yousef SA, Pastore MN, Telaprolu K, Mohammed YH, Namjoshi $\mathrm{S}$, Roberts MS. Skin models for the testing of transdermal drugs. Clin Pharmacol 2016; 8: 163

[193] Ruela ALM, Perissinato AG, de Sousa Lino ME, Mudrik PS, Pereira GR. Evaluation of skin absorption of drugs from topical and transdermal formulations. Braz J Pharm Sci 2016; 52: 527-544

[194] Moss GP, Gullick DR, Wilkinson SC. Predictive Methods in Percutaneous Absorption. Berlin: Springer; 2016: 25-42

[195] Shibayama H, Hisama M, Matsuda S, Ohtsuki M. Permeation and metabolism of a novel ascorbic acid derivative, disodium isostearyl 2-O-LAscorbyl phosphate, in human living skin equivalent models. Skin Pharmacol Physiol 2008; 21: 235-243 
[196] Batheja P, Song Y, Wertz P, Michniak-Kohn B. Effects of growth conditions on the barrier properties of a human skin equivalent. Pharm Res 2009; 26: 1689-1700

[197] Sengupta A, Lichti UF, Carlson BA, Ryscavage AO, Gladyshev VN, Yuspa SH, Hatfield DL. Selenoproteins are essential for proper keratinocyte function and skin development. PLoS One 2010; 5: e12249

[198] Liu X, Testa B, Fahr A. Lipophilicity and its relationship with passive drug permeation. Pharm Res 2010; 28: 962-977

[199] Song J, Kim YC, O E, Compans RW, Prausnitz MR, Kang S. DNA vaccination in the skin using microneedles improves protection against influenza. Mol Ther 2012; 20: 1472-1480

[200] Mizutani Y, Sun H, Ohno Y, Sassa T, Wakashima T, Obara M, Igarashi Y. Cooperative synthesis of ultra long-chain fatty acid and ceramide during keratinocyte differentiation. PLoS One 2013; 8: e67317

[201] Bin B, Joo Y, Lee A, Shin S, Cho E, Lee T. Novel inhibitory effect of N (2hydroxycyclohexyl)valiolamine on melanin production in a human skin model. Int J Mol Sci 2014; 15: 12188-12195

[202] Li CC, Lin YT, Chen YT, Sie SF, Chen-Yang YW. Improvement in UV protection retention capability and reduction in skin penetration of benzophenone-3 with mesoporous silica as drug carrier by encapsulation. J Photochem Photobiol B 2015; 148: 277-283

[203] Seino H, Arai Y, Nagao N, Ozawa N, Hamada K. Efficient percutaneous delivery of the antimelanogenic agent glabridin using cationic amphiphilic chitosan micelles. PLoS One 2016; 11: e0164061

[204] Ohno U, Kamiyama N, Nakamichi S, Kihara A. PNPLA1 is a transacylase essential for the generation of the skin barrier lipid $\omega$-O-acylceramide. Nat Commun 2017; 8: 14610
[205] Vizserálek G, Berkó S, Tóth G, Balogh R, Budai-Szűcs M, Csányi E, Takács-Novák K. Permeability test for transdermal and local therapeutic patches using Skin PAMPA method. Eur J Pharm Sci 2015; 76: 165172

[206] Netzlaff F, Schaefer UF, Lehr CM, Meiers P, Stahl ], Kietzmann F, Niedorf F. Comparison of bovine udder skin with human and porcine skin in percutaneous permeation experiments. Altern Lab Anim 2006; 34 : 499-513

[207] Godin B, Touitou E. Transdermal skin delivery: predictions for humans from in vivo, ex vivo and animal models. Adv Drug Deliv Rev 2007; 59: 1152-1161

[208] Roberts ME, Mueller KR. Comparisons of in vitro nitroglycerin (TNG) flux across Yucatan pig, hairless mouse, and human skins. Pharm Res 1990; 7: 673-676

[209] Sato K, Sugibayashi K, Morimoto Y. Species differences in percutaneous absorption of nicorandil. J Pharm Sci 1991; 80: 104-107

[210] Feetham H], Jeong HS, McKesey J, Wickless H, Jacobe H. Skin care and cosmeceuticals: attitudes and trends among trainees and educators. J Cosmet Dermatol 2017; 17: 220-226

[211] Costa R, Santos L. Delivery systems for cosmetics - from manufacturing to the skin of natural antioxidants. Powder Technol 2017; 322: 402-426

[212] Mohamed HM. Green, environment-friendly, analytical tools give insights in pharmaceuticals and cosmetics analysis. Trends Analyt Chem 2015; 66: 176-192

[213] Salvador A, Chisvert A. Analysis of cosmetic Products. 2nd ed. Valencia: Elsevier Science; 2017: 303-330 